\title{
NATURE AND HUMAN EQUALITY
}

\author{
John E. CoOns \\ Patrick M. BrenNan
}

If morals and ethics are not based on nature or on reality, then what else are or can they be based on?'

Nature loves to hide. ${ }^{2}$

\section{INTRODUCTION}

Our title will mislead, but so would any other. We intend no sermon on wealth redistribution or voting rights; nevertheless, "equality" is our subject. If only we could liberate that term from its contradictory uses in social philosophy, we might put equality to the purely descriptive task conceived for it by Jefferson. ${ }^{3}$ With that in mind, this essay first offers a meaning for "created equal." Having defined human equality, one intelligently could ask whether particular systems of moral philosophy allow such an idea. In this article, we will ask specifically whether human equality can be harmonized with various theories of natural law.

Please take literally our aim to be descriptive about equality. The premise here is not that humans should be more nearly equal but, rather, that all rational persons are-here and now-already equal in the unique and significant sense that we will shortly specify. Elsewhere we argue at length for this position; ${ }^{4}$ here we will do little more than assert our conclusions. Taking these as our premises, we can put our question to the natural lawyer. Can he believe such a thing?

\section{The Premise: Descriptive Human Equality}

There are, of course, multitudes of descriptive equalities that exist as relations among humans. We are all equal, for example, in

1. Henry Veatch, Human Rights Fact or Fancy? (1985), p. 214.

2. Heraclitus, fragment 22B 123 in H. Diels, Fragmente der Vorsokratiker (W. Krantz, ed. 1968).

3. Lincoln too made descriptive use of the term. Gary Wills' focus upon the egalitarian social vision of Lincoln is a well executed exaggeration. Gary Wills, Lincoln at Gettysburg (1992).

4. J. Coons and P. Brennan, Created Equal: Was Jefferson Right? (forthcoming, 1996). 
possessing weight; most of us are equal in possessing rationality; and most are equal also in possessing wealth. But such equalities of possession are of little practical interest. They hold true between a linebacker and a ballerina; they relate the pauper with ten dollars to the banker with ten million; and by possessing rationality, even Newton and I are clearly equals. This shared possession of any personal trait or of a material good generates a true relation of equality; but it is a truth that only obscures. For the important reality is that the pauper and the banker are as unequal in wealth as are Newton and $I$ in intelligence-and that the linebacker outweighs the ballerina. If human equality is anything significant, it will have to rest upon more than possession. Necessarily, it will be some form of what the authors call a double equality - a relation in which persons are uniform not only in possession of some good or power but also in the degree to which they enjoy it. Such relations are hard to find. Indeed, there appear to be no empirical properties that could form the ground of a double equality among the mass of mankind. In every measurable respect humans differ in degree. This is why egalitarian philosophers prefer to leave the issue of a descriptive equality in obscurity. ${ }^{5}$

These differences of endowment and luck, however, do not exclude the possibility of a human equality rooted in some non-empirical property. Equality could be a relation that holds among all rational persons in virtue of some trait that might be possessed in the same degree but that happens to be immeasurable. Its uniformity thus would be beyond proof-but a possibility; it might be different in degree, but it might not; its sameness would be a matter for belief or disbelief. ${ }^{6}$ Like the freedom of the human will, it would be unprovable but plausible. Perhaps human equality is like this.

If so, it both resembles and implicates another feature often recognized in all rational choosers-what is typically called "human dignity." From antiquity, religious believers and unbelievers alike have associated human dignity with those faculties-reason and willthat allow the self to commit either for or against a real good and

5. Rawls, for example, resorts to "range properties" that allow him to ignore the enormous variation in the degree of individual potential-for example, in the all-important "capacity for moral personality." John Rawls, A Theory of Justice (1971), pp. 506-08. And see Philip Selznick, The Moral Commonwealth (1992), pp. 482-84.

6. What it would not be is self-evident. To that extent Jefferson's art was purely political. However, Gary Wills shows how close Jefferson came to belief in equality as we here define it. Inventing America (1979). 
thereby to advance toward or recede from moral self-perfection. (The believers have been distinguished by their view that reason and will also constitute each human person the "image and likeness" of a common creator.) This version of dignity remains incomplete, however, in a crucial dimension. Specifically, neither antiquity, Judaism, Christianity, nor the twentieth century has asked-much less settledthe question whether dignity varies in degree. It could, of course, do so. It is plausible, for example, that dignity is relative to the degree of our individual moral acumen. Since plainly we differ in our intellectual powers, some of us could be more gifted than others at identifying the real good in particular cases. If true, would this not diversify our potential for moral self-perfection?

Socrates seemed to think so; for him, people who grasped more details of the good were simply better people; conversely, ignorance and vice were equivalent. Suppose that Socrates were correct. Human dignity-a quality that rests upon our capacity for moral choicewould then vary with the degree of the individual's intellectual power; it would be relativized. The moral potential of each person would be fixed by a cognitive yardstick. Each would have dignity, but some would have more than others. Christianity and the West as a whole have never clearly rejected this proposition; thus, to many in our culture, the same dignity that confirms our moral importance constitutes the medium of moral hierarchy. They conclude that we vary in our potential for what is really significant in human life. This judgment of theirs is no less consequential for being unconscious.

Dignity can be rescued from relativization only if humans stand in a relation of equality that is grounded upon these same structural elements of moral life. What could make such an equality credible? The literature is surprisingly thin even-or especially-among liberal social philosophers. The most serious effort to describe human equality as some sort of fact appears in Jacques Maritain's Redeeming the Time. ${ }^{7}$ It is worth our seeing how the central move of this modern scholastic-though both insightful and necessary-still leaves the ultimate question hanging. In his initial chapter entitled "Human Equality," Maritain tried to specify "the realist idea, the true idea of equality" in the following passages:

[T] he unity or equality in nature among men ... is ontological and concrete, just as much as the likenesses and affinities which in the external world serve as bases for that positive unity which the species has within our mind. For the universality of our ideas

7. Jacques Maritain, Redeeming the Time (1943), p. 1. 
is grounded in re, in things. ...

The equality in nature among men consists of their concrete communion in the mystery of the human species; it does not lie in an idea, it is hidden in the heart of the individual and of the concrete, in the roots of the substance of each man. ${ }^{8}$

What is clear enough is Maritain's conviction that the relation of equality is metaphysically real, being grounded in those same descriptive elements of human essence-reason and will-that justify the term "dignity." This insight-that the relation requires a realist metaphysic-is a pre-condition to understanding the nature of equality. But, again, it is not enough. Maritain has left our specific question unanswered and in a dangerous state. Humans might very well be equal in their common possession of the capacity for a reciprocal morality and for love. But if they enjoy that shared capacity in varying degrees, paradoxically it will constitute the medium of an ontological hierarchy; some of us will have greater facility for moral self-perfection than others. Maybe that is the way things are.

Let us call this threatening interpretation "gnostic;" it exalts the moral capacity of those who are intellectually gifted. Because they can know more, they are potentially superior. There is, however, a plausible alternative to this conclusion. We can in a realistic manner conceive of the human capacity for moral self-perfection as uniform in degree.

Here in barest form are the criteria we discern for such a human equality: First, equality is a relation; if you do not believe in relational reality, you cannot believe in equality. Second, because it is a relation, human equality must be grounded upon some host property that is possessed by each of two or more beings (in this case, persons). Third, the host property of the unique relation that is human equality must be one that is of fundamental importance to self-identitysome capacity that is a primary medium of moral self-perfection. Fourth, this subjective capacity must have as its object the real good of other humans (as well as the self). Finally, this capacity to seek or to reject the real good of others must also be uniform both in possession and in degree; that is, if human equality is to hold, all rational persons must have it and have it to the same extent.

These criteria suggest the following possibility: The host property of the unique relation of human equality is the capacity of every rational person to advance in moral perfection by exercising moral choice. It is the freedom of the self to commit to (or reject) the

8. Ibid., p. 15 . 
terms of a real, pre-institutional obligation to other humans insofar as these terms can be found by the individual. In making each moral choice the individual either accepts or rejects the primary obligation to seek the real good of himself and the community. Moral progress or regress of the person consists precisely in these decisions to submit to or to flout genuine responsibility. But here is the crucial point: the act that is effective to advance one's personal moral state is radically subjective; it is the personal choice to quest for the specific external good. Whether this honest search discloses the objectively correct answer in the particular instance is not significant to the moral state of the actor (though, of course, getting the answer straight is relevant to the natural good of the actor, other individuals, and of society). Moral self-perfection is effected solely by the effort to find and attempt that answer.

The pure subjectivity of the act of moral self-perfection is necessary to the existence of human equality, because the host property of the relation must be one which is uniform in degree as well as possession. If, instead, the potential for self-perfection were relativized and differentiated, it would-as we have said-constitute the medium of disequality. It is this consideration that disqualifies rationality itself as the host property for the relation. If the relation of human equality is to be, its host trait must be some property that could be either uniform or disuniform in degree-but that plausibly is uniform. The capacity to strive subjectively for the objective good is just such a trait. It is not by definition uniform in degree, but it might in fact be so. To believe that it is uniform constitutes the belief in the relation of human equality. This belief simultaneously delivers human dignity from relativization. ${ }^{9}$

Early in our work on descriptive equality, we decided to call the self-perfecting act of choice "obtension," a word that to us suggested simultaneously the subjectivity of the act and the objectivity of the good to which the act is directed as its ideal. Only later did we discover that it appears in Samuel Johnson's dictionary (and now the O.E.D.) bearing definitions roughly compatible with our own. Obtension is a useful addition to the discourse about the powers of the moral self and the process of its moral self-perfection. We shall

9. Well-intending persons thus morally perfect themselves even while committing objective injustice. This result entails no systemic threat to the common good. To the contrary, the belief in perfection-by-intention tends to raise individual moral aspiration above the level of the minimally correct. No person can do more than his best to discover the objective good, and whoever does less forfeits his own fulfillment. 
have frequent occasion to use the word throughout the balance of this essay.

\section{Who Could Believe This?}

Whether one can assent to the relation of human equality that is founded upon the uniform capacity for "obtension" will depend upon what else one believes. In our larger work we conclude as follows: (1) This description of equality is already implicitly credible for most Christians; (2) equality is incompatible with radical individualism and other moralities that are based solely upon human convention; (3) equality could be rendered plausible to various versions of natural law philosophy by refinement of traditional principles. The first two conclusions deserve a brief statement before we commence our focus upon the natural law.

First, consider the Christians. The implications of dogmatic Christian theology-Catholic and Protestant-are complex and often conflicting on the relevant questions. Historically, baptism, grace, and predestination have clouded any claim of an equal universal access to self-perfection (salvation). Nevertheless, from the earliest centuries, the possibility was recognized (if often rejected) that well-intending barbarians might have plenary capacity to accept salvation even without access to the gospel. ${ }^{10}$ Almost imperceptibly over time it has become an orthodox option to believe that a diligent conscience is sufficient to anyone's salvation whether conscience grasps or misses particular truth in the particular case. ${ }^{11}$ For example, one who mistakenly supposes a war to be just morally perfects himself by volunteering. This position is often vigorously opposed, but clearly the quarrel is now within the family.

Things stand rather differently for the typical Enlightenment philosophies. Hobbes is ineligible to assent to descriptive equality. The radical individualist does not seek morality but rather invents

10. See, e.g., Etienne Gilson, The Spirit of Medieval Philosophy (1940), p. 27; John Mahoney, The Making of Moral Theology (1987), pp. 101-02.

11. See, e.g., Lumen gentium \$16; Gaudiem et spes \$16.

The Council had precedents that, for whatever reason, it did not mention. The eighteenth century doctor of the Church, St. Alfonsus Liguori, for example, judged it the "more probable" and "most common" view that to act in accord with an invincibly erroneous conscience is not only required (and "excused," as St. Thomas held) but good and perfecting. See Theologia Moralis, 1.I, par. 6, in Opere Morali di S. Alfonso Maria de Liguori (1846), vol. 5, p. 2. Compare the discussion in D. Prümmer, Manuale Theologiae Moralis (1958), Vol. I, Pars I, Tract. IV, §313, pp. 205-06, for a Thomistic attempt to disarm this potent doctrine that implies human equality. 
it. Thus, by definition, the clever and educated person has greater moral capacity, and human equality fails. This is not the only reason Hobbes and company must reject equality, but it is sufficient. In every purely conventional morality the capacity of the individual varies according to his or her cognitive horsepower; hence it forbids equality and relativizes dignity.

Which brings us at last to our principal question: How does human equality stand among those who assert that morality and self-perfection are linked to "nature"? The answer may depend upon the particular version of natural law, and there are many.

\section{An InTRoduction to the VoICES of Nature}

Whether nature is a clue to the good (or even is the good) has steadily engaged the mind of the West since antiquity. The Greeks conceived the question and endlessly elaborated its answers; the Romans took it up, invested it with legal significance, and bequeathed it to the medieval theologians, philosophers, and canonists; ${ }^{12}$ they in turn made it a cornerstone of ambitious and influential moral systems. Eventually it became the preoccupation of the Protestants Grotius and Pufendorf and the Anglican Hooker, passing through them to moderns such as Locke and Rousseau who gave it their own twist. ${ }^{13}$ Nor is it merely of literary or historical interest. In the 1990's "natural law" became the stuff of American politics. In successive years during hearings on Supreme Court nominations the same discerning U.S. Senator first complained that Judge Bork rejected natural law and then that Judge Thomas embraced it. An alert press noted the apparent tergiversation, but the Senator explained it all in The

12. See e.g., Sophocles, Antigone, ii. 452-60; Aristotle, Nicomachean Ethics, V.7, 1134bl8-1135al, Physics, II.8, 198bl0-199b32; Cicero, De Legibus, De Re Publica, III, xxii, and $c f$. De Finibus, III \& IV (Cicero here emphasizes the role of intention in a way that at first was promising to us; at the end of the moral day, however, the result was the predictable one: intention can make an act bad, but cannot make a person good. See III.ix); Justinian, Corpus iuris civilis, Institutiones (P. Krüger, T. Mommsen and R. Schoell, eds. 1892), Lib. I, Tit. II; Gratian, The Treatise on Laws with the Ordinary Gloss (A. Thompson and J. Gordley, trans. 1992), D.1 c.7.

13. Hugo Grotius, De jure belli ac pacis (W. Whewell, ed.), Prolegomena; Samuel Pufendorf, De jure naturae et gentium II. 2-3; Richard Hooker, of the Laws of Ecclesiastical Polity (A. McGrade, ed. 1989), I.10, 15; John Locke, Questions Concerning the Law of Nature (Horwitz et al., eds. 1990); Jean Jacques Rousseau, "The Second Discourse"' in The First and Second Discourses (R. Masters, ed. 1964). 
Washington Post: There are, he said, a good natural law and a bad natural law. ${ }^{14}$ Grateful for this insight, the authors are committed to a search for the latter, all in the hope that good natural law will harmonize with human equality.

There are countless conceptions of this natural morality and no one dominating example that we can test for compatibility with human equality. ${ }^{15}$ Nevertheless, in the midst of its "many mansions" 16 there is a common element, one that disposes all natural law theory toward what we have called obtensionalism-or commitment to a real good. The common element is what natural lawyers often describe as the objectivity of the good: natural law claims to rest upon an order of good and evil that holds apart from human preference and obligates the individual. Rejecting the fickle commands of individualism, subjectivism, and pure convention, natural law declares nature to be an immutable guide for human conduct:

"Nature" - the image of a reality possessed of an origin, a solidity, and a stability independent of human intervention; a sign for what does not depend on human desire or design; and because of these special characteristics, endowed with an authority that is normative for human conduct. ${ }^{17}$

The belief that there is a natural standard obligating all humans is the common core of the diverse traditions of natural law, for

14. See Joseph Biden, Jr., "Law and Natural Law: Questions for Judge Thomas" in The Washington Post, September 8, 1991, p. Cl. See also Phillip Johnson, "The Modernist Impasse in Law" (unpublished paper, November 19, 1991, on file, Boalt Hall, University of California, Berkeley); Philip Soper, "Some Natural Confusions About Natural Law," 90 Mich. L. Rev. (1992), pp. 2393, 2403-09.

15. Rousseau observed, "[k]nowing nature so little, and agreeing so poorly upon the meaning of the word law, it would be very difficult to agree upon a good definition of natural law." Rousseau, The First and Second Discourses, 95 (Preface to "Discourse on the Origins and Foundations of Inequality"). Hobbes took much the same view: "All authors agree not concerning the definition of the natural law, who notwithstanding do very often make use of this term in their writings ...." Thomas Hobbes, Philosophical Rudiments Concerning Government in English Works (W. Molesworth, ed. 1841), II. 14.

One sour contemporary assessment has it: "There are many natural law theories, some less objectionable than others." Jeffrey Stout, "Truth, Natural Law and Ethical Theory" in Natural Law Theory (Robert George, ed. 1992) pp. 71, 83. Another: "[P]hilosophers tend to say that the natural law is not natural and lawyers tend to say that it is not a law." Michael Crowe, "Natural Law Theory Today" in The Future of Ethics and Moral Theology (1968), p. 78.

16. Kai Nielsen, Ethics Without God (1990), p. 38.

17. John T. Noonan, Jr., "The Metaphors of Morals" in Riding Time Like A River: The Catholic Moral Tradition Since Vatican II (W. O'Brien, ed. 1993), pp. 35, 36. And see Murdoch, Metaphysics as a Guide to Morals (1992), pp. 360 et seq. 
"whatever else it may or may not be, the natural law philosophy is not relativist." 18 Unlike human devices it will not bend on command to ratify our personal or collective preferences. It challenges our prejudices and warns us from even the most exigent or alluring. Until Machiavelli dispensed the prince, it would not yield even to the extreme plight of the Italian states and the city of Florence. ${ }^{19}$

Natural law thus seems to satisfy several of the criteria of descriptive equality. (1) It recognizes and honors the individual capacity for moral choice. (2) It affirms that through exercise of that capacity the individual has the potential to achieve moral perfection. (3) It asserts that the individual must at least seek diligently the specific terms of a distinctive order of lateral obligation that is antecedent to any human law or correction. The hard question that remains may be whether, by demanding that we grasp these terms correctly, natural law forbids equality. For it must also satisfy the fourth and fifth criteria: That is, for equality's sake (4) natural law must allow for the achievement of moral self-perfection simply by obtensionby a diligent search for the terms of lateral obligation that are fixed by nature; and, finally, (5) it also must concede to every rational human an ability to obtend that is uniform in degree.

Can natural law assimilate the fourth and fifth criteria? For that inquiry we will examine separately four significant but distinctive understandings of natural law. ${ }^{20}$ The first we label the Common Sense

18. Philip Selznick, "Sociology and Natural Law," 6 Natural L. Forum (1961), pp. 84, 91 .

19. Machiavelli was a watershed in natural law theory. "It is this rock [of the natural law]," writes Isaiah Berlin, "upon which western beliefs and lives had been founded, that Machiavelli seems, in effect, to have split open." ("The Originality of Machiavelli" in Isaiah Berlin, Against the Current (H. Harold, ed. 1981), p. 38. Unlike Hobbes and his radical individualist successors, Machiavelli did not deny the existence of the natural law; his signal accomplishment was to suppose that there could be exigencies so critical that some people (viz., the new prince) could, indeed must, disregard the natural law. While Machiavelli continued to recognize the reality of a nature to act against, he proposed the novel suggestion that moral selfperfection might come-for a limited few, in limited circumstances-from doing what is contrary to nature. (See Sebastian de Grazia, Machiavelli in Hell (1989); cf. John Geerken, "Elements of Natural Law Theory in Machiavelli"' in The Medieval Tradition of Natural Law (H. Johnson, ed. 1987), p. 37. The Hobbesian belief that nature is morally mute was the quick and easy expansion of Machiavelli's exception.

20. Obviously, "the laws of nature" taken as empirical science are not our topic. Our interest is not in a law of nature as a description of phenomena, but in natural law as a norm and guide to human moral self-perfection. (See A.P. d'Entreves, Natural Law: An Introduction to Legal Philosophy (1951), pp. 7, 10-11). We are also uninterested in those common American renditions of natural law as an uncontroversial statement of the minima of social justice. (See Lon Fuller, The 
version. It is the stuff of cocktail parties and Senate hearings with an ancient and enduring appeal. Second, we examine the Renaissanceor what we shall call the Classic-view of Francisco Suarez; while Suarez invokes the common sense notions of nature, we will find his theory more divine than natural. Third, we look at the most prominent contemporary account of "natural law," one that seemingly replaces nature with "reason;" adopting an expression of its creators, we call this version the natural law of "integral human fulfillment," or simply Integration. Fourth, we develop the natural law implications of the work of the twentieth-century philosopher, Bernard Lonergan; for the moment let us call this the natural Vocation to Responsibility. It is potentially congenial to the fourth and fifth criteria of human equality; Lonergan's understanding of "objectivity" accommodates the idea of moral self-perfection by best effort that is the key to human equality.

These moral theories all assert a natural and objective morality, but they differ regarding the source of personal obligation. Again there are four contenders for the role of source: (1) things themselves; (2) divine command; (3) self-evident human goods; and (4) an interiorly given vocation to "responsibility." Each locus presents its own problems and possibilities for equality. ${ }^{21}$

Morality of Law (1969); Russell Hittinger, "Natural Law and Virtue" in Natural Law Theory, p. 42). Note, finally, that despite their labels, the literary inventions by the Enlightenment of "states of nature" also do not qualify for discussion here. This fictional device was (and remains) a favorite of moralists looking to escape theocratic sources without dishing morality itself. Thrusting amoral man into a fictional "state of nature," they have him consent through social contract to all manner of government and civil society including forms of social equality. Each of these stories is more about a pre-institutional environment and its resolution and less about the human self and its innate capacity for moral self-perfection. To that extent they are less hostile to the self of human equality than they are irrelevant. The comparisons we must make are not among contingent conditions of the world that the self inhabits but, rather, among concepts of the selves that do the inhabiting.

21. Our neglect of Aquinas is not an oversight. No one should dispute that he would command a place in any fair consideration of the history of natural law theorizing, but we found that the issue of equality comes into bolder relief in the comparison of other natural law theories. In any case, each of these four theories claims the Dumb Ox as support, and each may be correct.

Our own inclination is toward the understanding of Aquinas' doctrine of natural law proposed by Stephen L. Brock, The Legal Character of Natural Law According to St. Thomas Aquinas (unpublished dissertation, University of Toronto, 1988); accord James P. Reilly, Jr., "Saint Thomas on Law" (The Etienne Gilson Lecture, 1988). On Brock's reading, natural law is a part of, and fully satisfies, Aquinas' general definition of law. That is, it is a rule instituted and promulgated for the common good by him who has control of the whole community, viz. God. Natural law remains a fully natural law, however, because to be governed by the natural 
Our general conclusions will be that neither the Common Sense nor the Classic view of natural law is comfortable with equality; both make self-perfection depend upon accurate moral judgments followed by corresponding action. The fallible self's conscientious quest for the good is not sufficient. In short, these two traditional versions of natural law are forms of moral gnosticism; they require correct grasp of specific duties. They agree with-and were shaped by-Gratian's judgment that "ignorance of the natural law is damnable for adults." 22 If, between them, they exhausted the subject of natural law, human equality would be left as unsupported by nature as it is by individualism. This would leave us a bit uneasy. Natural law is often portrayed as the sole morality shared by all humans-the only one that is independent of religious belief. So viewed, it has broad importance to the possibility of a human equality. Could an authentic natural law exist without this insistence upon getting things right? This may yet be the case. The third and fourth versions have been selected for description here specifically because of their self-conscious departures from the gnostic standard. There is at least some hope that the version we call Integration will accept moral self-perfection by obtension; and, in the case of Bernard Lonergan, the only question will be whether his conception of morality can properly be designated "natural law."

\section{Natural Law as the Matching of Natures: The Common Sense Position ${ }^{23}$}

The Common Sense version of natural law received its shape from the biology, physics, and metaphysics of Aristotle, though he himself

law man need not know that it was God who promulgated it. Knowledge of the natural law is "knowledge, albeit imperfect, of the very order that the eternal law has instituted or imposed upon God's creatures, even if it is not yet a comprehension of this order in its properly divine or eternal being, nor even an awareness of the fact of its eternal institution by a divine legislator." (Ibid. p. 119). So far so good for equality. But what Brock must conclude later is threatening. "Even if the original understanding of the principles of natural law is immediate and requires no advertence to God whatsoever, the theoretical judgment on the truth of these principles is rather closely connected with their status as laws of God. And their status as laws of God is much more easily grasped with the help of revelation than through any process of human reasoning." (Ibid. p. 251 (citation omitted)). The problem for equality, once again, is the gnostic advantage of those who encounter revelation over those who do not.

Natural law is, in any event, only one of the aspects under which Aquinas describes man's morality; we consider the non-legal ones in Chapter 9 of our Created Equal.

22. See The Making of Moral Theology, pp. 193-94 n. 60.

23. As we proceed to disparage Common Sense natural law, we should be careful 
probably would find it an extravagant extension of his own premises. ${ }^{24}$ In any case, this habit of moralizing from the appearances of nature is too ubiquitous to ignore; nor is it confined to the uneducated. ${ }^{25}$

to spare that broader version of common sense on which we have rested our own position. Our project has supposed that obtensionalism is not our own invention but is, rather, that version of morality and of the moral self that-for consistencymust be believed by those who claim that humans are descriptively equal. We think that most people do implicitly assent to obtensionalism because they believe in equality (or vice versa). The capitalized version of common sense that we now examine is different. It is a species of low-tech natural law thinking. As we shall see, it is not in fact especially common sensical but a rather blunt form of physicalism that scants the intentional side of morality.

24. When we had nearly finished our work on natural law we discovered Mortimer Adler's The Time of Our Lives: The Ethics of Common Sense (1970). In it, Adler expounds and develops the ethical theory of Aristotle's Nicomachean Ethics, which Adler explains is both teleological and deontological. (The Time of Our Lives, pp. 157-200, 241-245). It differs in important respects from the rather crude teleology we label Common Sense. But there was in Adler confirmation of our determination that Common Sense has roots in Aristotle: "As Aristotle is uniquely the philosopher of common sense, so his moral philosophy is uniquely the ethics of common sense." (Ibid. p. 236). See Henry Veatch, Rational Man: A Modern Interpretation of Aristotelian Ethics (1964), pp. 69-71; Vernon Bourke, "Two Approaches to Natural Law," 1 Natural L. Forum (1956), p. 92.

25. We have in mind the following sorts of statements:

"There is a universal moral law, as distinct from a moral code, which consists of certain statements of fact about the nature of man; and by behaving in conformity with which man enjoys his true freedom. This is what the Christian Church calls 'the natural law.' ... The universal moral law (or natural law of humanity) is discoverable, like any other law of nature, by experience. It cannot be promulgated, it can only be ascertained, because it is a question not of opinion but of fact. . . . At the back of the Christian moral code we find a number of pronouncements about the moral law, which are not regulations at all, but which purport to be statements of fact about man and the universe. . . . These statements do not rest on human consent; they are either true or false. If they are true, man runs counter to them at his own peril." Dorothy Sayers, The Mind of the Maker (1979), pp. 911 .

"Now this Law or Rule about Right and Wrong used to be called the Law of Nature. Nowadays, when we talk of the 'laws of nature' we usually mean things like gravitation, or heredity, or the laws of chemistry. But when the older thinkers called the Law of Right and Wrong the 'Law of Nature,' they really meant the Law of Human Nature. The idea was that, just as all bodies are governed by the law of gravitation and organisms by biological laws, so the creature man had his law - with this great difference ...., [that] a man could choose either to obey the Law of Human Nature or to disobey it. . . This law was called the Law of Nature because people thought that every one knew it by nature and did not need to be taught it. ... [T] aking the race as a whole, they thought that the human idea of decent behavior was obvious to every one." C.S. Lewis, Mere Christianity (1952), p. 18. Cf. A.P. d'Entreves, "The Case For Natural Law Re-examined," 1 Natural L. Forum (1956), pp. 1, 44-45.

"Reason reads the natural law in the nature of all things and particularly in the nature of man. To say that reason is able to read the law written in the heart of 
It is also a valuable entree to the other three versions, and we shall try to see it in the round.

The Common Sense analysis of morality begins, as did Hobbes, with a picture of what is unique and essential to being human. But where the individualist focuses on the human will, Common Sense identifies reason as the key element. Reason "produces" morality and does so almost accidentally. Rather than freely spinning it out in a series of choices, reason generates morality almost as a byproduct of its characteristic activity: knowing. And knowing occurs in complete dependence on the senses. As touch, sight, taste, and the rest go to work they bring man into sensate contact with material reality. And from sensation intellectual awareness or understanding follows immediately; sense experience fructifies into knowledge. As reason "produces" this knowledge of things, it delivers to us the content of responsibility. But, of course, on this view it is really things that determine the content of morality; all reason does is to put the mind into "correspondence" with them. ${ }^{26}$

Thus, at the center of Common Sense morality stand sensible things; but at the center of each and every one of these things stands in turn what Common Sense calls a nature. This nature is its core or stable essence. It is what a thing really is. It is by knowing this that one knows the thing, as distinguished from its variable or "accidental" characteristics. It is the difference between, on the one hand, knowing Bill Clinton and, on the other, knowing where Bill happens to be this quadrennium. The straightforward message of Common Sense is that the human mind can and does know the natures of things and that this knowledge is (1) necessary, and (2) sufficient to put us under specific moral obligation.

The sense in which knowledge of things is necessary to morality is plain enough. Even if morality were but a collection of divine (supernatural) commands, one would still have to be able by use of

man means simply that reason is able to grasp the law of nature from the ontological reality of man and of all things." Joseph Fuchs, Natural Law: A Theological Investigation (Dublin: Gill \& Son, 1965), 8 (here Fuchs is paraphrasing an Allocution of Pope Pius XII; we consider Fuchs's own moral theory in our Created Equal, Chapter 9).

26. For a classic statement of this essentialist (or quidditative) aspect of morality, see "Reality and the Good" in Josef Pieper, Living the Truth (1989), pp. 109-77. "[A]ction is really determined by the objective reality itself." (Ibid., p. 144). "[R]eason is nothing but the 'passage' to reality. . . . An insight into the nature of the good as rooted in objective being, of itself compels us to carry it out in a definite human attitude, and it makes certain attitudes impossible. . . 'Objectivity,' if thereby we mean 'fidelity to being,' is the proper attitude of man." Ibid., p. 113. 
the senses to distinguish particular things and persons (for example, spouses) from other things and persons. But the sense in which such knowledge is sufficient to morality is not so clear. How does knowing what a thing is show what one ought to do? How, in other words, does knowing the essence of a thing put one under an obligation to treat it in a particular way?

The systematizers of Common Sense offer something like the following explanation: ${ }^{27}$ We come to know the nature of a thing not all at once, but by our experience of it as it goes through change. Most of the change that things undergo is not random but orderly and the result of principles internal to them. By discovering a thing's principles of change and growth we discover not only what it essentially is, but what it is trying to become. And these dynamic principles are the basis of obligation. In the dynamic connection between potentiality and actuality "[t]he ontological and moral orders are ultimately one.... A basis for value exists only in the tendency of something incomplete to complete itself." 28

Thus for Common Sense morality, we experience things, we come to know their natures as we discover their inner, dynamic principles of change, and eventually we discover the gap to be closed between the potency and the actuality of each thing. This is what is known as its "finality" or "final causality." This concept was not new with Aristotle, but he put it on the map, and with him it is forever associated. ${ }^{29}$ The stock-in-trade of the tradition, it has slipped or been shoved into desuetude and so requires some reintroduction. A contemporary account of Aristotle's understanding of final causality puts it this way:

[Julian Huxley's] idea is that the highest existing thing at any moment of time is the sum of the world and its contents-inorganic and organic nature with man at the head-at the state of evolution which at that moment it has reached. Aristotle remained too much of a Platonist to think like this. For him there could be no progress that was not progress toward something, and you could not progress towards something unless it existed. . . . [S]ince nothing in nature can surpass its own specific form, everything has its own telos, to realize in itself the form which nature intended it to embody. . . . ${ }^{30}$

27. For a typical exposition of this neo-Aristotelian, but-not-quite-natural-law position, see Jude Dougherty, "What Judge Thomas Did Not Say," 69 The Modern Schoolman (1992), p. 400.

28. Ibid. See also George's discussion of Veatch's position in Robert George, "Natural Law and Human Nature" in Natural Law Theory, pp. 31, 33.

29. See Aristotle, Physics, 11.3, 194b32-195a2.

30. W.K.C. Guthrie, A History of Greek Philosophy, Vol VI. Aristotle: An 
A thing's finality is its end or goal, and what it already is potentially; and it is this inner, constitutive principle of a thing that specifies what the rational agent must do. This is the core of Common Sense morality: "The very essence of any natural-law ethics is that there should be a veritable natural end, or natural perfection, or natural telos, of human life, discernible empirically and directly in the facts of nature." 31

Common Sense itself grasps that this picture is too simple. For one thing, there are conflicts among the yearnings (finalities) of the natures that persons encounter and experience. The food chain consists of such conflicts; the yearnings of the hungry human conflict with those of the growing carrot and the grazing cow. And among the contending natures that a person experiences is his or her own; we experience contradiction among our own dynamic yearnings to move from potentiality into ever greater actuality.

This array of conflicts poses a deep problem for a morality founded on natural finalities. If the morality is to remain real, Common Sense cannot leave man's undirected preferences to resolve the conflicts. That would be a form of subjectivism. If it is not to sacrifice its objectivity, nature must identify the correct alternative. Now, according to Common Sense, it does. While the fundamental location of obligation is in the dynamic principles within all things, nature itself has worked out the pecking order. It tells reason which natures trump other natures. It does this through the real relations or "matches" that exist among things. "The order of nature is a vast complexus of such intelligible relations. As part of that natural order, each man is able to discern those things and actions that are

Encounter (1981), pp. 117-18. See also Jacques Maritain, Moral Philosophy (1964), p. 58: "It is with Aristotle that this notion is put sharply in relief. With him it is linked not with the archetypal idea, but with the essence or intelligible nature which is within things as the primary 'form' by which they exist and act. This essence is within things but it is grasped separately and in its universality by the mind, and it implies ideal exigencies; and things act normally only if they respond effectively to these exigencies of their essence and tend straightly to the end it implies. For in Aristotle's dynamic conception all essence is the assignment of an end, a teloswhich beings endowed with reason pursue freely, not by necessity. Become in your action what you are in your essence-here is the primordial rule of ethics." See also Walter Farrell, The Natural Moral Law According to St. Thomas and Suarez (dissertation, University of Fribourg, Switzerland [1930]), p. 132; Leo Strauss, Natural Right and History (1953), pp. 7-8; Human Rights, pp. 68-86.

31. Ibid., p. 56. 
really fitting for him. ... Moral law is nothing but the expression of what is fitting for human agents in view of their significant relations with other beings." 32 Here is a more elaborate description from the same author:

Prior to ethical rules expressive of types of right actions are those objective and real relations between persons, between things, and between various interpersonal dealings. These relations are understandable "ratios" (in a wider sense than the arithmetic) which provide an objective basis for reasoning to moral judgments. Some of these practical judgments are general in form, for example, that children should respect their parents, or that parents should take care of their children. In other words, there is a right ratio between parent and child, not simply because I think so but because of a universal relationship. ${ }^{33}$

In the next section we will see that the Renaissance version of natural law takes issue on philosophic grounds with the claims of the Common Sense moralists. Our immediate interest is only whether a Common Sense natural lawyer can accept obtensionalism. What he plainly does accept is the raw availability of the information that is necessary to moral choice, and that at first seems promising for equality. No revelation, rarified intuition, or heady calculus must be had in order for us all to know at the sensible level what things are, hence, what to do. The authors have had some difficulty locating (or understanding) the all important "complexus of relations," but we are willing to assume that it is out there, as Common Sense tells us. ${ }^{34}$ Thus, at the surface everything one needs to know can be deemed available for inspection.

The problem is that people differ in their capacity to penetrate the natures of things and to discern the serpentine twists of the "complexus." It is a point we have already considered. And, this discrepancy in relative acumen becomes doubly important when we

32. Vernon Bourke, History of Ethics (1968), p. 90.

33. Vernon Bourke, "Is Thomas Aquinas A Natural Law Ethicist?," 58 The Monist (1974), pp. 52, 65. Cf. Jacques Maritain, "Natural Law and Moral Law" in The Moral Principles of Action: Man's Ethical Imperative (R. Anshen, ed. 1952), pp. 62, 62-63: "[I]n its ontological aspect Natural Law is an ideal order or a divide between the suitable and the unsuitable, the proper and the improper, which depends on human nature and its essential ends. In this first consideration (ontological) Natural Law is co-extensive with the whole field of moral regulations which concern man as man-even if they are grounded on the most subtle and refined considerations - with the whole field of ethical philosophy, as universally valid."

34. The word complexus has a long history in the Latin language and many denotations, but Bourke's meaning here seems to be the core one of a "union" or "coming together." 
recognize that-even if they are accessible to cognition-things and their relations are not truly so plain as the Common Sense moralizer would have it. Whatever the limits of modern psychology, it has clearly grasped that with every cognitive nature goes the baggage of its personal history. Things cannot be known in splendid purity. There is grave reason to worry that men will have uneven success in finding the way.

This would not be fatal to equality, if common sense taught that self-perfection is not impeded by "unnatural" acts as such but, rather, that it depends decisively on the intention to get things right. But that is not its message. On this crucial point, even today Common Sense draws its spirit from Greek antiquity. Its intellectual forebears put the moral question in this form: "What am I to do if I am to fare well?"'3s The Greeks merged the idea of morality with that of earthly happiness and set the tone for legions of successors. ${ }^{36}$ This is unsurprising and requires no apologies from Aquinas and the rest, but it does compromise equality by leaving a great deal to luck. ${ }^{37}$ Aristotle's own elaborations of happiness make this clear. In detail he explains that happiness is the attainment of a "complex totality: the best and most beautiful life, the accomplished fullness of human

35. This quotation from MacIntyre continues: "Modern ethics asks, what ought I do if I am to do right? and it asks this question in such a way that doing right is made something quite independent of faring well." Alasdair MacIntyre, $A$ Short History of Ethics (1966), p. 84. See also Martha Nussbaum, The Fragility of Goodness (1986), p. 5; Bernard Williams, Ethics and the Limits of Philosophy (1985). See also Werner Jaeger, Paideia: The Ideals of Greek Culture (1961), III, pp. 25-26, I, pp. 303-04.

36. Aquinas is merely one among many others who shape ethics around man's unrelenting quest for happiness. See generally Georg Wieland, "Happiness: the perfection of man" in The Cambridge History of Later Medieval Philosophy (N. Kretzman et al., eds. 1982), p. 673.

For an example of a theorist who distinguishes and then conflates moral and nonmoral goodness, see Veatch, Rational Man, p. 71 (citation omitted): "Accordingly, whether we call it human perfection or human happiness, human moral goodness or human well-being, it is obvious that, on such a view of ethics, human excellence or virtue will be, in Plato's words, 'a kind of health and beauty and good habit of the soul; and vice will be a disease and sickness and deformity of it.' Lowes Dickinson once aptly observed, 'It follows that it is as natural to seek virtue and to avoid vice as to seek health and avoid disease.",

37. "Natural law is not a written law. Men know it with greater or less difficulty, and in different degrees, running the risk of error here as elsewhere. . . That every sort of error and deviation is possible in the determination of these things [of the natural law] merely proves that our sight is weak, our nature coarse, and that innumerable accidents can corrupt our judgment." Jacques Maritain, "Natural Law in Aquinas" in Readings in Moral Theology, No. 7 (C. Curran and R. McCormick, eds. 1991), pp. 114, 118. 
nature, happiness-consisting in the true order of the parts which compose it." ${ }^{38}$ It is the achievement of a whole range of goods. Man must live in a polis; he must possess goods and leisure enough to contemplate things divine; he must possess and exercise the virtues with pleasure; he must enjoy art and be completed with friendship. ${ }^{39}$

Antiquity was by no means unanimous in locating human happiness in this constellation of human excellences and contentment. ${ }^{40}$ Plato had earlier identified human happiness with the philosopher in contemplation. That answer appealed to him, because it minimizes happiness' vulnerability to the fates. His is still no easy path, because it is difficult to become a philosopher; but the happiness to which Aristotle aspires is even more elusive. Maritain, making the contrast to Plato, protests the contingency of Aristotelian moral success:

The sovereign good, Happiness, has been brought back to earth, humanized, adapted to the structure and to the essential aspirations of our nature. Yes, but it involves so many ingredients and so many conditions which are hardly attainable-even for a small number of individuals, for a limited aristocracy of philosophers. . . . Our whole moral life, all our effort and striving toward rightness and virtue, are suspended from an End which, in fact, eludes us, vanishes within our grasp. ${ }^{41}$

Equality too protests this old Greek version of self-perfection and its merger in the Common Sense tradition. It makes room for so few of us. To begin, there are no children to be found among the moral heroes of Common Sense and Aristotle. In an ethics formed around finality, perfection is apt to be understood as what is attained "at the end of a long term, after long exercise, at a ripe age when the hair is beginning to turn silver." 42 Kings, savants-and perhaps soldiers and farmers-can all be pictured as reaching moral perfection, their natural finality. ${ }^{43}$ But such moral ripeness is impossible to the

38. Moral Philosophy, p. 34.

39. Ibid., p. 48. See Aristotle, Nicomachean Ethics, I.7, 1098al7-19 ("[O]ne swallow does not make a summer . . . and . . . a short time does not make a man blessed and happy."); I.8, 1099a31-1099b8; I.10, 1101al4-20; X.6-9, 1176a30-1181b25; VII.13, 1153b16-21; Magna Moralia, II.8, 1206b30-35. See The Fragility of Goodness, pp. 318-372; cf. 373-77.

40. Indeed, Aristotle can be read as correcting the abstract excesses of Plato.

41. Moral Philosophy, pp. 47-48.

42. Ibid., p. 33.

43. But even this is not so clear:

[A] boy is not happy; for he is not yet capable of such acts, owing to his age; and boys who are called happy are being congratulated by reason of the hopes we have for them. For there is required, as we said, not only complete virtue but also a complete life, since many changes occur in life, and all manner of 
child. This picture of moral gradualism, of a perfection realizable only by survivors, is just what equality forbids. Self-perfection cannot be the special achievement of those who fortuitously survive to apply the final touches in maturity. Equality requires plenary moral power for every reasoning being, including those. who are new at the game. It somehow must swallow even the hard case of the child who dies (or who loses rationality) having experienced only the "faint flicker of choice" and only the promising beginnings of natural excellence. ${ }^{44}$ By posing the question as they did, the Greeks may have ensured for human aspiration a stimulus toward all that is good and fulfilling within a human culture; but simultaneously they guaranteed that its achievement would be confined to a few. Those who, despite their best effort, fall short could be left with little that mattered.

Consider but one example-the fate of Oedipus. Subjectively, he was innocent of the atrocities that crushed him: Oedipus himself understood them as his destiny; it was the will of Apollo that he kill his father and sleep with his mother. Yet his lack of "responsibility" for the doing of such unnatural acts was no moral redemption. Oedipus' essential "status" was determined precisely by this behavior. His "subjective" innocence was beside the point, and the question whether he was morally self-perfecting is subsumed in his "tragedy."

Now Oedipus is surely to be pitied; the harms he caused were for him a humiliation, and his life was an objective failure. Sophocles has insured him the permanent label "tragic." But, though this usage survives, we wish to emphasize that this is an antiquitarian view of tragedy-one that largely reduces the significance of a life to its objective deeds. As we have noted, and will again, Western religion and its humanism initiated the historic drift away from such extreme objectivity and toward a competing understanding-one that limits tragedy to cases of voluntary withdrawal from responsibility. ${ }^{45}$ Tragedy is, strictly speaking, no longer necessary; it must be chosen.

If Oedipus is still perceived by us as tragic, this could be only in some third sense-specifically that it was a tragedy for him to have

chances, and the most prosperous may fall into great misfortunes in old age, as is told of Priam in the Trojan Cycle; and one who has experienced such chances and has ended wretchedly no one calls happy.

Nicomachean Ethics I.9, 1100a1.

44. John Coons, "The Religious Rights of Children," Religious Human Rights (John Witte, ed. 1996).

45. See Created Equal, Ch. 4. 
lived in a society that had not yet grasped the distinction. ${ }^{46} \mathrm{We}$ would add only that, to the extent that Common Sense natural law still lacks this distinction, it turns the hope for equality into this third sort of tragedy; equality requires for its existence that the good be accessible to the innocent regardless of their "fate."

\section{The Natural Law of Conformtty and Divine Command: The Classic Position}

Between the fourteenth and seventeenth centuries Common Sense and its purely natural sophistications lost their monopoly over natural law. While final causality was to remain an important element in natural morality, it was increasingly regarded as insufficient by itself to ground obligation. Modern critics explain what was missing: "The trouble with natural law was precisely that it had no author.... The point of the matter has always been that natural law itself needed

46. Even Dodds can be read to share this perception:

Oedipus is great . . . in virtue of his . . . strength to pursue the truth at whatever personal cost, and strength to accept it and endure it when found. "This horror is mine," he cries, "and none but I is strong enough to bear it." Oedipus is great because he accepts the responsibility for all his acts, including those which are objectively most horrible, though subjectively innocent.

E.R. Dodds, "On Misunderstanding the Oedipus Rex" in Greece and Rome (1966) XIII, pp. 37, 48. Cf. Stanley Hauerwas, Truthfulness and Tragedy (1977), pp. 6470.

No doubt there are many possible meanings for "tragedy," and the specifically Greek idea of it had the signal virtue of assuring that the Greeks would write the most perfect specimens of one great form of literature. We also agree (pace Plato) with the conclusion of Aristotle and Nussbaum that human life is genuinely diminished by disease, loneliness and lucklessness. Nussbaum is correct: "I am an agent, but also a plant." (The Fragility of Goodness, p. 5). What the authors and what equality could not accept is that the highest human worth-moral worth-is snatched away in the withering of the plant. Nussbaum insists:

How many who live together really live together, "sharing in speech and reason"? ... It is, in fact, an extraordinary demand to make on the world; those who make it are likely to be unhappy. But since the goal of the Aristotelian is not so much happiness in the sense of contentment as it is fullness of life and richness of value, it is no solution to omit a value for happiness's sake, to reduce your demands on the world in order to get more pleasing answers from the world. The Aristotelian will simply take on the world and see what can be done with it.

Ibid., p. 369.

But this refuses-deliberately-even to distinguish between moral and non-moral goods. Nussbaum thereby creates what is to us a false dilemma. Equality omits no value, and it encourages contentment; it insists only that the highest kind of personal worth, even in those who have the least control of their environment, is invulnerable to chance. 
divine sanction to become binding for men."47 Some moralists responded by junking the natural law for a God-given substitute. ${ }^{48}$ Others, however, were not so ready to give up on natural law, and in their hands it came to include God's command. Divine will was invoked to reinforce nature's own causality, providing the necessary authorship. Unlikely as this combination of nature plus God may seem, it is the quintessential scholastic presentation of the natural law that emerged from the medieval period. ${ }^{49}$ It came down to this century by way of the Latin "manuals" that dominated moral debate until recent days, and so we denominate it the Classic position. ${ }^{50}$ The manuals tended to treat the natural law as a rigid edifice of highly specific rules (mostly prohibitions), and for this the manuals are today regarded as an embarrassing excess of moral theory. ${ }^{51}$ But notwithstanding the scorn that has been heaped upon the manuals, the detail and specificity of much contemporary natural lawyering illustrate that the manualistic spirit continues. To assess the compatibility of this brand of moral theory with equality, we recur to Francisco Suarez (1548-1617), who conferred its modern charter. ${ }^{52}$

47. Hannah Arendt, On Revolution (1977), p. 190. For another statement of this "trouble" with natural law, see Yves Simon, The Tradition of Natural Law (1965), pp. 110-45, espec. 136-45. See also, Kai Nielsen, "The Myth of Natural Law" in Law and Philosophy (S. Hook, ed. 1964), pp. 122, 129 ("If there is no God ... . [then] the classical natural law theory is absurd."'); G.E.M. Anscombe, "Modern Moral Philosophy" in The Collected Philosophical Papers of G.E.M. Anscombe, Vol. 3, Ethics, Religion and Politics (1981), pp. 26, 30-31; "Truth, Natural Law and Ethical Theory," p. 95.

48. See Created Equal, Chs. 7-9.

49. And the one most often pilloried by critics who suppose it to be the theory of natural law. An admirable effort to rescue natural law from this disreputable association is Michael Moore, "Good Without God," delivered at the Conference on Liberalism, Modernity and Natural Law of the American Public Philosophy Institute (Sept. 17, 1993).

50. See, e.g. I. Gury, S.I., Compendium Theologiae Moralis (1907), Vol. I, pp. $122-23, \S 122$ n.1: “Objectum vero legis naturalis formale non quidem in convenientia cum natura rationali, non in perfectione eidem naturae debita, quae ideo quaerenda sit, neque in necessitate quadam aut convenientia cum felici statu naturae humanae sive in individuis, sive in societate debet reponi; sed in ratione praecepti a Deo hominibus impositi; adeo ut dictamen rationis haberi debeat tanquam promulgatio divinae ordinationis, seu signum divinae voluntatis aut praecipientis aut vetantis. Unde illud s. Anselmi: Quicumque legi naturali obviat, Dei voluntatem non servat. Quocirca concinne ac proprie definiri lex naturalis posset: Iudicium intellectus de voluntate Dei supremi naturae gubernatoris, mala vetantis ac bona praecipientis."

51. See, e.g., James M. Gustafson, Protestant and Roman Catholic Ethics: Prospects for Rapprochement (1978), pp. 46-47 et passim; Charles E. Curran, Directions in Fundamental Moral Theology (1985), p. 126.

52. See e.g., History of Ethics, p. 124: "It would be difficult to overstate the scope of Suarez's influence in ethics. Many of the leading modern. philosophers 
Standing Janus-like at the beginning of the seventeenth century, Suarez was enough of a traditionalist to suppose that nature founds an objective morality; at the same time he was enough of a modernistand a legist ${ }^{53}$-to conclude that moral obligation requires a surer source than mere nature. What it wanted was sovereign will-a command. Finally, Suarez was enough of a theist to believe that God issued that command.

If we squint just a little, the notion of the natural law that is discoverable in Suarez reduces to an academicized form of Common Sense. ${ }^{54}$ Some signal changes appear in the details, but the traditional references to the "intrinsic" quality of obligation are there..$^{55}$ Still prominent is the "match" between natures that remains, as it were, the basis of specific moral obligation. Suarez refers to it as the "conformity" or harmony between human rational nature and some other nature. ${ }^{36}$ Finally, such "conformity" is just as real as "things" themselves. It arises automatically once human rational nature and the relevant other nature are posited. ${ }^{57}$

Opening our eyes a little wider, however, the points of apparent commonality with Common Sense begin to diverge in a distinctly different understanding of "conformity." Common Sense had held that knowledge of the "match" or conformity emerged from simple experience of natures, their growth, and possible interaction. A match was a judgment about how things ought to interact; and knowledge of matches was a grasp of the fixtures of the real world. By contrast, the Classic understanding severs ${ }^{58}$ moral knowledge from its root in

studied ethics in textbooks written from a partly Suarezian viewpoint. The seventeenth century saw the publication of dozens of manuals of moral philosophy written by both Catholic and Protestant ethicians. In most of these academic books the ethics of Suarez has some influence."

53. Suarez had been a law student before becoming a Jesuit. Ibid., p. 123.

54. All references to the text of Suarez are to the Tractatus de Legibus, ac Deo Legislatore [1612] by Book, Chapter and Section. The translations are from Selections From Three Works of Francisco Suarez (1944), Vol. II, although in a few places we have adapted the translation using the text of the Tractatus de Legibus in Francisco Suarez, Opera Omnia. (C. Berton, ed. 1856), Vols. 5 \& 6.

55. E.g., ibid., H.XV.18; II.V.2.

56. Ibid., II.V.9; II.V.3. The "as it were" is necessary because, as we shall see, while Suarez on the one hand maintains that it is the real relation of man's rational nature to other natures that founds these conformities, his predominating opinion is that they are contained not in the world, but in a set of deductive propositions. The two positions appear to us incompatible.

57. Ibid., Il.XV.18. Cf. John Finnis, Natural Law and Natural Rights (1988), pp. $45-46,59,61$.

58. "As a result of this diminished reality in the universality of a nature, Suarez is forced to adopt a teaching on ethical obligation that stresses the having of this oughtness as God's will." History of Ethics, p. 122. 
the being of the things to be compared. Where once there were real things, there now are only propositions. Gone is the empiricality of Common Sense, and in its stead looms a labyrinth of deductions. With serene confidence, Suarez declares that from the most general principles to the most specific conclusions, ${ }^{99}$ "every judgment derived from the natural law is of such a character that it rests either upon self-evident principles or upon deductions necessarily drawn therefrom; and, therefore, however much things themselves may vary, there can never be a variation in such judgment." 60

The component premises of this deductive edifice are of three classes. Those in the first class are primary, general, and self-evident; we encounter such principles as "one must do good, and shun evil," and "do not to another that which you would not wish done to yourself." Those in the second class, though "more definite and specific," are also self-evident. "Examples ... a are these principles: 'justice must be observed'; 'God must be worshipped'; 'one must live temperately'; and so forth." Finally, there are those in the third class-conclusions that are "deduced" from the more general principles. "Of these conclusions, some are recognized more easily than others, and by a greater number of persons;" thus adultery, theft and "similar acts" are plainly wrong. For other acts the conclusions come with greater difficulty, requiring "reflection ... of a sort not easily within the capacity of all;" we must struggle to see "that fornication is intrinsically evil, that usury is unjust, that lying can never be justified." 61 Indeed, some of these conclusions require "a great deal of elaborate reasoning." 62

But still the complications multiply. Suarez perceives that even if one manages all the deductions with the rigor of Euclid, one might fail to grasp the basic point that the natural law actually governs us. The only thing that correct deduction can reveal is that certain acts are suitable to be done-not that anyone is obligated to do them. In discovering a "match" - a real relation between things-the Common Sense natural lawyer knew at once what to do and that he must do it. By contrast, in his deductions the Classic natural lawyer learns only what would be suitable. If he is actually obligated to do it, this is not because it is suitable. These conformities among natures

59. Tractatus de Legibus, II.VII.5

60. Ibid., II.XIII.3; see also II.XIII.9; II.XVI.3; II.VIII.3.

61. Ibid., II.VII.5.

62. Ibid., II.VII.6. 
are not law. ${ }^{63}$ Indeed, properly speaking, there is no natural law without a divine command, coming from within rational nature, telling us to realize what reason discovers to be a potential conformity and to avoid disconformity. ${ }^{64}$

[T] he natural law, as it exists in man, does not merely indicate what is evil, but actually obliges us to avoid the same; and ... it ... does not merely point out the natural disharmony of a particular act or object, with rational nature, but is also a manifestation of the divine will prohibiting that act or object. ${ }^{65}$

Absent the divine command, these acts would be unsuitable, but not prohibited. ${ }^{66}$

Obviously, humans do not have formal knowledge of this divine command, or else the law would not be natural. Instead, God's command that we obey nature is promulgated to us obliquely-and not without more effort on our part. Proper reflection shows us that it is necessary that a fitting Providence should issue such a command. ${ }^{67}$ This oblique awareness, Suarez concludes, is sufficient, "no other notification [of the divine command] being necessary." The natural light of reason makes clear to man that God wills us to do the good and avoid the evil. ${ }^{68}$

Common Sense supported an obligation of an intrinsic sort, dictated by things themselves. With our eyes now fully open, we see that it

63. "[I]n the end the function of reason remains purely informative, not legislative." Louis Dupré, Passage to Modernity: An Essay in the Hermeneutics of Nature and Culture (1993), p. 137.

64. See Tractus de Legibus, II.VI.11-13; II.V.9; II.V.5; II.VI.5-6.

65. Ibid., II.VI.13.

66. See The Natural Moral Law, pp. 148-54. See also History of Ethics, p. 123: "Natural law has an obligatory force from the will of God ...." See Tractatus de Legibus, II.VI.17. See The Legal Character of Natural Law According to St. Thomas Aquinas, p. 45 n.8: "Suarez also qualifies the naturalness of natural law, in accordance with his position that natural law is a law insofar as it constitutes a sign of God's will or of the eternal law. In his view, the order contained in the precepts of natural law is identical with, and a reflection of, the order instituted by the eternal law."

67. Tractatus de Legibus, II.V1.23. The argument runs that from the time God freely willed to create humans with the capacity to know and do good and evil, God was obliged to command that humans so act, for it would be "in the highest degree foreign to the divine wisdom and goodness" to fail to command humans to do what is good and avoid what is evil. "The morality caused by the Natural Moral Law is indeed distinct from the 'natural honesty and malice' of acts, according to Suarez, yet de facto these two moralities are inseparable and God cannot refrain from commanding and prohibiting the acts which form the subject matter of the Natural Moral Law." The Natural Moral Law, p. 122.

68. Tractatus de Legibus, II.VI.24. See II.VI.8; II.VI.12-13. 
has been eclipsed by obligation of an extrinsic sort. ${ }^{69}$ It is God's will, not nature, that obliges man. Of course, the notion that God's will is law was at least as old as Exodus. And the force of God's image as Lawgiver had become particularly prominent in the nominalist morality of the late Middle Ages. Suarez welded that image to nature.

Would this hybrid natural law square with the structure of human equality? Within the Classic version can the person self-perfect by obtending the real good? Suarez does not discuss the possibility that one could be blamelessly ignorant of the divine command. But he does have a few surprising things to say about the likelihood and effect of innocent ignorance of the content of the natural law. Ignorance of the primary principles is impossible; of the more particular principles, ignorance is possible, "yet such ignorance cannot exist without guilt; not, at least, for any great length of time." But with respect to the other precepts that require "greater reflection, invincible ignorance is possible, especially on the part of the multitude. . . . The reason for this, is self evident." 70 One indication of the possible scope of this ignorance is Suarez's judgment that many know the Decalogue (part of the natural law) only through scripture. ${ }^{71}$ For him knowledge of the natural law is not complete among individual humans. ${ }^{22}$

Yet regarding culpability, Suarez blithely asserts that this obscurity is of "slight importance." 73 The existence of a precept obliges man to know it, ${ }^{74}$ and "the moral question"-man's obligation-is not "particularly affected by how much reflection is involved." 75 The fact that common people are most typically ignorant of the particular precepts is also irrelevant. These precepts are the means of perfection, and the person who is not in fact guided by them will remain incomplete; he will not be self-perfecting. The content of the natural law is what is necessary for the perfection or felicity of human nature. ${ }^{76}$ Ungoverned by the precepts of the natural law, human

69. In this fundamental Suarez differs from Aquinas: Whereas for Suarez " $[t] h e$ human judgment cannot cause an obligation; it can only manifest this obligation which is the result of an act of the will of God," for Aquinas "[t]he precept or proposition of natural reason is a true secondary cause producing a real effect, sc. a real obligation." The Natural Moral Law, p. 148.

70. Tractatus de Legibus, II.VIII.7.

71. Ibid., Intro. to Bk. II. See II.IX.6.

72. Ibid., II.VIII.5; II.VIII.3; cf. II.XV.15.

73. Ibid., II.XIV.6.

74. Ibid., p. II.X.10.

75. Ibid., p. II.VII.10. Suarez hedges with the Latin word "parum," which we translate as "particularly.",

76. Ibid., p. II.VII.7; II.VIII.4. 
conduct lacks "rectitude." The subject who fails to do the natural law stands imperfect, his potential unfulfilled. ${ }^{77}$

More complex than Common Sense natural law, the Classic version is at one with it in rejecting fulfillment by good intention-even by the specific good intention to seek the content of the Suarezian rules of conduct. The wrong choice never produces moral goodness in the actor-whatever the intention. Hence, the savant with his or her superior grasp of the details will have the easier access to selfperfection. This is descriptive inequality. ${ }^{78}$

\section{The Natural Law of "Integral Human Fulfillment"}

Most of Post-Enlightenment theory took Kant seriously when he declared that morality "has nothing to support it in heaven or earth." 79 In such a climate, the gradual petrifaction of the manuals' already brittle Suarezian propositions made the stewards of the Latin moral theology increasingly uneasy. By the late nineteenth century, a crisis of confidence drove them to creative efforts to re-conceive the basic idea. In the last hundred years, works of this sort have appeared in two basic types. The first of these were revivals and restatements of the Common Sense school. Natural lawyers of this type have reintroduced and reintegrated the ancient notions of natures, potency, and act, and finality-all to support traditional morality. With Henry Veatch they continue to ask where morals could ever be based, if not in nature or reality.

77. See ibid., II.VII.4; II.IV.4; II.VII.10; II.VIII.4. These two formulations, one having to do with natural perfection, the other with "rectitude," seem to reflect the duality in Suarez's conception of the natural law: natural finality and command. Cf. Preface to De Legibus.

78. The mitigating doctrine of epikeia is impotent to avert this result. Epikeia is a transliteration of the Greek term, usually rendered in Latin as equitas and in English as "equity," for the doctrine that prevents the application of a law where its application would be contrary to the fairness of the lawgiver. One must "conjecture" the mind of the lawgiver, asking whether he would have willed the application of the law in the particular circumstances. The doctrine has its origins in Aristotle and his analysis of positive law, and it is to the realm of positive law and a human lawgiver that the medievals generally confined it [see Lawrence Riley, The History, Nature and Use of EPIKEIA in Moral Theology (1948), pp. 276-85)], and on this Suarez is typical (Tractatus de Legibus, XVI.7. 9-11, 13-15). There were, however, exceptions. See The Making of Moral Theology, pp. 237-44, espec. 241; EPIKEIA, pp. 263-66; Josef Fuchs, "Epikeia Applied to Natural Law?" in Personal Responsibility and Christian Morality (W. Cleves, trans. 1983), pp. 185-99.

79. Immanuel Kant, Fundamental Principles of the Metaphysics of Morals in Kant's Critique of Practical Reason and Other Works on the Theory of Ethics (T. Abbot, trans. 1909), p. 43. 
The other distinct type is the subject of this sub-section, and remains unimpressed with Common Sense. It agrees that morals are to be grounded in reality, and even in natures, but it denies that nature itself is the source of the moral ought. And, resisting the temptation to take recourse in divine command, it locates the moral ought somewhere between heaven and earth-in a reality that is at once familiar and obscure: the self-evident principles of practical reason. We shall spend some effort figuring out what they are and whether they generate a morality that harmonizes with equality. Because its proponents are at great pains to limit nature's function in founding morality, some have suggested that this is not a natural law theory at all.$^{80}$ But it is regarded as such by its primary proponents, John Finnis and Germain Grisez, as well as by a host of collaborators and critics, and we shall concur. Our shorthand for it is Integration, because "integral human fulfillment" is its moral measure.

The most direct way to understand Integration is not, we think, to consider it in isolation. More than most theories, it defines itself by its enemies. It takes its shape, on the one side, from the Scylla of Common Sense, and, on the other, from the Charybdis of Classic. Classic is to be avoided because a quasi-natural divine command solves no problems and creates new ones. Quite apart from the eventuality that no such command reaches people, the Finissians insist that, even if it did, it would give us no moral guidance; we would still need to know how to treat quasi-divine commands. An infinite regress looms. ${ }^{81}$

80. Cf., "Truth, Natural Law and Ethical Theory," p. 95: "Many theorists decided that something less cosmological, something having to do with human nature or practical reason or collective intersubjectivity, would have to be substituted for the traditional correspondence relation if the notion of moral truth was to be retained. Some of the resulting programmes, which I am calling anti-realist, called themselves natural law theories, but they were hardly of the traditional kind." See also "Natural Law and Human Nature," p. 31: "As Hittinger understands Grisez's theory, it suffers from a 'failure to interrelate systematically practical reason with a philosophy of nature.' In other words, it fails to do the very thing that makes a theory of practical reasoning and morality a natural law theory" (citation omitted).

81. Finnis' and Grisez's criticism of the traditional natural law theories clarifies their own theory in these respects. "[T]he scholastic natural law theory must be rejected. It moves by a logically illicit step-from human nature as a given reality, to what ought and what ought not to be chosen. Its proponents attempt to reinforce this move, from what is to what ought to be, by appealing to God's command. But for two reasons this fails to help matters. First, unless there is a logically prior moral norm indicating that God's commands are to be obeyed, any command of God considered by itself would merely be another fact which tells us nothing about how we ought to respond. Second, even leaving this problem aside, the difficulty remains that human persons are unlike other natural entities; it is not human nature 
Integration understands that Classic resorts to a command because nature gives no moral messages. A nature is only what is, and therefore is impotent to say what ought to be. Any attempt to coax an "ought" out of it flirts with what the professionals know as the "naturalistic fallacy." W2 While many defenders of Common Sense deny that it commits the dreaded fallacy (the ought, they say, is given with the is, no inference being necessary), Integration takes the fallacy seriously, thinks Common Sense violates it, and so looks elsewhere for the terrestrial moral ought.

To be fair to Integration, it does not divorce itself altogether from nature. Indeed, it is as we experience human nature that we become familiar with its possibility; we grasp what would be fulfilling. We know, in other words, what is good for it. And presently we grasp that the good is to be done-but this is not by a process of inference. Rather, simply in grasping what is good for human nature, we know at once that it is to be done. According to Finnis and Grisez, the most basic source of human obligation is a group of self-evident or intrinsic goods. These "[i]ntrinsic goods are basic reasons for action precisely because they are (intrinsic) aspects of human well-being and fulfillment." 83 We are dealing here with the very foundations-the so-called "first principles"-of morality.

The most basic reasons for action are those reasons whose intelligibility does not depend on deeper or still more fundamental reasons. As basic reasons, they cannot be derived; for there is nothing more fundamental that could serve as a premiss for a logical derivation. Therefore, they must be self-evident. ${ }^{84}$

as a given, but possible human fulfillment which must provide the intelligible norms for free choices." Germain Grisez, The Way of the Lord Jesus. Vol I. Christian Moral Principles (1983), p. 105 (citations and italics omitted). See also Natural Law and Natural Rights, pp. 42-46, 342-43, 348-50; Germain Grisez, "The First Principle of Practical Reason: A Commentary on the Summa Theologiae Question 94, Article 2," 10 Natural L. Forum (1965), p. 168. Cf. Russell Hittinger, A Critique of the New Natural Law Theory (1987), pp. 14-20.

82. Hans Jonas has convinced us that the "naturalistic fallacy" is a labor-saving dogma-and a mere tautology-of the anti-metaphysical empiricists. (See Hans Jonas, The Imperative of Responsibility (1984), p. 44 et seq.). This does not, of course, make it false, but that is not our present concern.

83. "Natural Law and Human Nature," p. 34.

84. Ibid. Notice that, contra Common Sense and Classic, on this account "practical knowledge cannot have its truth by conformity to what is known. Rather, a practical proposition is true by anticipating the realization of that which is possible through acting in conformity with that proposition, and by directing one's action toward that realization." Germain Grisez, Joseph Boyle, and John Finnis, "Practical Principles, Moral Truth, and Ultimate Ends," 32 Am. J. Juris. (1987), pp. 99, 114, 116. 
Finnis and Grisez have equivocated a bit regarding which goods are basic but seem to have settled on a list of seven: life; knowledge; play; aesthetic experience; sociability (friendship); practical reasonableness; and religion (understood as peace with some morethan-human source of meaning and value). ${ }^{85}$

In this little package of self-evident goods we have, according to Finnis and Grisez, the nucleus of morality. Now, it may seem that everything in their basic formula happened much too fast; the rabbit sprang undetected from the hat even under our watchful gaze. This, however, is to be expected in a theory that rests upon self-evidences. Finnis and Grisez have, "in effect, excuse[d] themselves from providing metaphysical or ontological grounds" for morality. ${ }^{86}$ There is, of course, little that can be said to prove (or disprove) a self-evident theory, but Finnis and Grisez do leave this opening: Self-evidence is not an experience of irresistible and immediate recognition. What is in itself self-evident is not equally self-evident to all people. It takes time and experience to grasp the basic goods. But whether or not the individual understands them, the basic goods remain the fundamental principles of human conduct. They are what give humans reason to act. They provide human conduct both its form and its content. ${ }^{87}$ And, once the basic goods do become self-evident to the observer, "there will not be mistakes about the goods themselves, as the categories of benefit people have reason to seek." 88

Because each of the basic goods is a first principle, they cannot be distinguished in dignity from one another or from some other, more basic standard. All seven are-simply-fundamental. ${ }^{89}$ It

85. See Natural Law and Natural Rights, pp. 59-99, espec. 85-90; "Practical Principles, Moral Truth, and Ultimate Ends,"' pp. 106-08.

86. "Natural Law and Human Nature," p. 31.

Insofar as it constitutes an "is," it is surprising that Finnis et al. do not proceed to infer the descriptive content of the underlying human nature. That is, if humans are creatures who grasp this sort of self-evidence, it is surely because of some inferable natural properties. If Finnis has hold of something real-an ought that is-he is entitled to move retrospectively to declare its underlying natural grounds and not merely to move forward to announce principles of morality. In this retroprocess, no naturalistic fallacy of the classic sort would occur. That the Finnissians do not make this move may betray that the origins of their system lie less in selfevidence than in the modern natural lawyer's allergic reaction to the is/ought critics of traditional natural law.

87. A Critique of the New Natural Law Theory, p. 38.

88. Letter of Joseph Boyle to Brennan, July 6, 1992.

89. See Natural Law and Natural Rights, pp. 92-95. "The distinguishing characteristic of Finnis' system is the independence of one value from another so that each is self-asserting because of its intrinsic worth." Terence Kennedy, "The Originality of John Finnis' Conception of the Natural Law" in Readings in Moral Theology No. 7, pp. 124, 132. 
follows-say the Finnisians-that the possibilities for human action cannot be reduced to some uniquely correct solution. No pre-existent pattern is prescriptive. Countless combinations are possible. Grisez emphasizes that it is because "human persons have possibilities which are not yet defined, [that] there is ... room for them to unfold themselves through intelligent creativity and freedom." 90 Practical reasonableness (their phrase) requires only that human choice be directed by the basic goods-that those goods provide the point to what one does. ${ }^{91}$

But "practical reasonableness" is not yet morality. The form and structure that the basic goods give to human conduct are in themselves an insufficient basis for morality, because "[e]ven morally bad actions have their point." Moral evil comes from the (reasonable) choice of some partial good thereby effecting the (unreasonable) neglect of that whole good that ought to dominate the moral quest. Choice of a partial good is, indeed, reasonable so far as it goes. Thus, to the basic goods that demand that one be reasonable in one's action, Finnis et al. must and do add what is called the first principle of morality-namely that one not simply avoid pointlessness but that one be entirely reasonable in one's practical deliberation. Apparently this means that in all choices reason must pursue exclusively the basic goods. Finnis puts it this way:

The fundamental principle of moral thought is simply the demand to be fully rational: In so far as it is in your power, allow nothing but the basic reasons for action to shape your practical thinking as you find, develop and use your opportunities to pursue human flourishing through your chosen actions-be entirely reasonable. ${ }^{93}$

This formulation of the "first principle of morality" seems ripe to our purpose. It identifies "reasonableness" as the criterion of morality, but it explicitly limits this requirement to what is in one's power. Moral achievement is no longer hostage to correct knowledge and the realization of a completely predetermined natural finality. Rather, it is the consequence solely of choices made in personal commitment to the self-evident goods. While Finnis and Grisez do

90. Christian Moral Principles, p. 105. To claim that the human must "unfold" himself strikes us as coming rather close to the position to be avoided: that man has a completely pre-given nature to which moral acts must correspond.

91. Abstracted from the seven basic goods in which it is given, this principle is known as the first principle of practical reason.

92. "Practical Principles, Moral Truth, and Ultimate Ends," p. 121.

93. John Finnis, "Natural Law and Legal Reasoning," 38 Clev. S. L. Rev. (1990), pp. 1, 3. 
not specifically say that best effort by itself is perfecting, equality would be at home in the moral universe they describe. The alliance between natural law and human equality becomes plausible. ${ }^{94}$

For better or worse, however, this flirtation with equality vaporizes when Finnis and Grisez add the final criterion of moral achievement that they label "integral human fulfillment." Up to this point they seem to agree that conduct that is motivated exclusively by the basic goods (i.e., fully reasonable conduct) is morally perfecting. This could mean, however, that even if one's conduct were to be directed exclusively by only one of the basic goods, the benign effect would follow. This possibility properly worries Finnis and Grisez. Moral self-perfection could be achieved while neglecting any number of the basic goods; the perfected person could be lopsided-zealously pursuing knowledge, for example, to the exclusion of friendship. It is particularly worrisome to them that religion might be among the basic goods that get slighted.95

Enter the final requirement:

The point of being practically reasonable is not: being practically reasonable, full stop. Rather, it is: participating in all the human goods well. "Well," here, expresses the implications not of some further, external (e.g. "moral") standard, but simply of all those human goods to be participated in, integrally, in each and all of one's self-constitutive choices. ${ }^{96}$

Elsewhere integral human fulfillment is described in these terms:

Integral human fulfillment is not a basic good alongside the others, nor some sort of supergood transcending all other categories of goodness. For integral human fulfillment is not a reason for acting, but an ideal whose attractiveness depends on all the reasons for acting which can appeal to morally good people. ${ }^{97}$

Finnis and Grisez are careful to emphasize the ideality and non-basic status of integral human fulfillment, and thus to try to remain true to their starting point in the foundational authority of the seven

94. It is important to note a point that we are not emphasizing. Even moral reasoning and conduct that are guided exclusively by the basic goods can be mistaken as to what acts will instantiate the basic goods. We consider this to be of little significance to equality, however, because, if moral self-perfection is achieved-as Finnis appears to claim-through conduct motivated and guided exclusively by the basic goods, whether action in fact instantiates a basic good will be morally irrelevant to the good of the actor, for that is determined by whether conduct is guided (and guided exclusively) by the basic goods.

95. Cf. "Practical Principles, Moral Truth, and Ultimate Ends," pp. 127-28.

96. John Finnis, Fundamentals of Ethics (1987), p. 72.

97. “Practical Principles, Moral Truth, and Ultimate Ends," p. 132. 
basic goods. Nevertheless, we suspect that they have here introduced what is a theoretically unmotivated and unallowable ghost of moral theories past-a vestigial image of the human nature they earlier exiled from moral philosophy. ${ }^{98}$ The person of integral human fulfillment looks surprisingly like the human nature of the traditional natural law theories. ${ }^{99} \mathrm{He}$ also looks a lot like the "ideal Christian;" he certainly does not use artificial contraception. ${ }^{100}$ Significantly, Finnis and Grisez attribute a large, though disputed, role to religion in clarifying the ideal of integral human fulfillment. ${ }^{101}$ If, as appears, the "revealed data of faith" enter into the very foundations of the theory, we have here a fideism that blocks equality by giving weight to correct perceptions. ${ }^{102}$

Integral human fulfillment may not lay down a detailed template of the perfecting human life, but it presents a pattern sufficient to raise doubts of the possibility of equality. These doubts are increased by the judgment of an occasional collaborator with Finnis and Grisez. In a letter to one of the authors he observes that "I am not sure what you ... mean by "does his best but still gets it wrong." ${ }_{103} \mathrm{We}$ can appreciate the puzzlement. In a sincere attempt to engage the equality issue as we posed it, he considers a number of permutations of the "does his best but gets it wrong" theme. He excuses the person who does an intrinsically evil act, because he had to act without sufficient reflection; but he will not concede that in making this choice this mistaken person is morally perfected. Erroneous conscience only binds; the well-intentioned bungler cannot be celebrated. ${ }^{104}$

98. "[W]hile the basic goods, considered as principles of practical knowledge, are not ordered among themselves, it does not follow that these principles are an unordered crowd. Prior to anyone's choice, unfettered practical reason, together with the conditions which human nature inevitably sets for moral life, establish certain natural priorities among a good person's basic interests. It follows that these priorities set necessary conditions for any morally good life plan." Ibid., p. 138.

99. Cf. "Natural Law and Human Nature," pp. 35-36; and $c f$. Ralph McInerny, Ethica Thomistica (1982), pp. 48-56.

100. See Human Rights, p. 96: "It is almost as though [Finnis and Grisez] were trying to salvage a natural-law ethic by denying that moral laws are really natural laws."

101. See A Critique of the New Natural Law Theory, pp. 93-154.

102. R. A. Connor, review of Russell Hittinger's $A$ Critique of the New Natural Law Theory in 33 Am. J. Juris. (1988), pp. 250, 254, 255-56.

103. Boyle to Brennan, July 6, 1992.

104. "By 'immoral choice' I mean a free choice to reject integral human fulfillment as identified according to the requirements of practical reasonableness." Fundamen- 
In its fundamentals Integration at first seemed amenable to equality, asking only that one realize the first principle of morality to the best of one's ability. But to the extent that integral human fulfillment requires an intellectual achievement, equality fades. And when faith enters to clarify details of necessary moral activity, descriptive equality ceases to be an option.

\section{The Objectivity of the Natural Law Reconceived as AUTHENTIC SUBJECTIVITY}

- With results such as these, the reader poised on the threshold of yet a fourth sub-section on natural philosophy may wonder why anyone would bother. The answer is that this final version, still recognizable as a theory of natural law, offers reconciliation with equality by perfecting our understanding of the "objectivity" that is central to natural law thinking.

The existence of a pre-institutional moral order-one that binds us independently of our knowledge and consent-is a criterion of human equality and one that is congenial to every version of natural law. The three schools we have canvassed tend to use the label "objective" to describe the action that a correct application of reason would disclose to be required in the particular case. In addition the moral actor is himself described as "objective" when he achieves correspondence between his own intelligence (and will) and the correct external event.

We have repeatedly identified the grave difficulty for equality theory that arises from this version of objectivity. It is the flip side to individualism; instead of subjectivism we now confront an excessive objectivism. If moral self-perfection requires that we successfully "correspond" with something outside ourselves, humankind is arrayed in a cognitive moral hierarchy. People's intellectual capacities for finding what is already-out-there are different; one's natural endowment, experience, and luck together affect one's ability to grasp the particular terms of the external moral order. Hence, those with better equipment for discovering correct answers have an advantage in the quest for moral fulfillment. Upon the cognitive

tals of Ethics, p. 151.

Robert George, another member of the Finnis camp, is in accord: "men can [make themselves moral] only by freely choosing to do the right thing for the right reason." Robert George, Making Men Moral: Civil Liberties and Public Morality (1993), p. 1. 
hierarchy there supervenes a moral hierarchy, and equality fails once again.

This conclusion can be avoided-as we have avoided it-if moral achievement comes not to those whose free choices actually correspond to the external order, but to those who try to achieve such correspondence. This is "obtensionalism," and it allows human equality, because everyone plausibly has the same capacity to try. But so far this view has not gained the allegiance (or even the attention) of the natural law. Indeed, to most natural lawyers obtensionalism may appear to sidestep rather than conquer the antagonism between human equality and objectivity. That is, to them obtensionalism appears to finesse the need to make objectivity something that everyone can achieve equally. It blithely concedes that the capacity for correspondence to the external order will vary, while reserving moral credit for the effort to achieve it; and it is solely for that effort that our capacities could be equal. This apparent antagonism with human equality might be eliminable, however, given a clearer picture of objectivity's proper meaning and role within a natural morality.

It is the singular achievement of Bernard Lonergan (1904-1984) to have re-conceived objectivity as the product of fidelity to an internally given moral order. Lonergan's position is hard-won as a piece of philosophy; it could hardly be otherwise: He seeks to reverse some of the most ancient philosophic positions. Lonergan's iconoclastic insight is, in a manner of speaking, all about rocks-the right rock and the wrong rocks. ${ }^{105}$

According to Lonergan, the basic, tacit, unanalyzed and generally wrong assumption of most thought, both inside and out of the

105. Lonergan is a systematic thinker with a relentlessness that would match even the most decadent scholastic. Because, for reasons that will appear, Lonergan bases ethics on the most foundational level, there is no "easy" way to get his take on natural law. In our exposition and analysis of his work we have quoted his own language liberally. There is good reason for this. Though his intellectual roots stretch to the depths of the Peripatetic tradition, Lonergan is his own intellectual man, one who calls his readers to a "conversion" away from ancient philosophic prejudices. His language and style are tailored to this task.

There are at least four useful, general introductions to Lonergan's work. Frederick Crowe, Lonergan (1991); Hugo Meynell, An Introduction to the Philosophy of Bernard Lonergan (1991); Patrick Byrne, "The Fabric of Lonergan's Thought" in Lonergan Workshop (Fred Lawrence, ed. 1986), pp. 1-84; David Tracy, The Achievement of Bernard Lonergan (1970) (completed before Lonergan had finished what he regarded as his magnum opus).

A superb, if difficult, introduction to Lonergan's ethics is Frederick Crowe, "An Exploration of Lonergan's New Notion of Value" in Appropriating the Lonergan Idea (Michael Vertin, ed. 1988), p. S1. 
academy, is that human knowing is essentially like seeing; that what we can glimpse out there, if we can just get an unobscured look, is the real. When we speak of objective knowledge, either practical or theoretical, we tend to mean that the mind corresponds to the real that we truly "see." This enduring and popular view is, according to Lonergan, "a bundle of blunders." 106 It calls for reversal.

The reversal begins with Lonergan's attack on the ideal of cognitive correspondence. The fallacy is easy enough to spot. Because we are always on the inside of being, there is no way to get outside (with Nagel) to "check" whether our supposed knowledge really corresponds to what is "out there." 107 Correspondence in that sense is an otiose doctrine; it presupposes the utterly unachievable act of "checking" the identity between thought and thing. ${ }^{108}$ In words that could almost be Lonergan's, Richard Rorty counsels, "[w]e should not regret our inability to perform a feat no one has any idea how to perform." 109

To renounce the ideal of correspondence between the mind and "external" reality is to take only the first step toward reinterpreting objectivity. The lure of externality is hard to quash. Whether we see (sic) it or not, we tend to remain in the grip of the ocular metaphor and are apt to seek the objective by casting our eyes upon the external world. But sight reveals no imperturbable rock; what is "out there" can never guarantee the accuracy of our knowledge, and so the ocular metaphor becomes less illuminating than mesmerizing.

But even if objectivity cannot be guaranteed because correspondence to the external world cannot be ratified, our hope for a rock need not disappear into the sand of skepticism. "There is," explains Lonergan, "a rock on which one can build." 110 To discover it, however, one forgets about correspondence with things external, kicks

106. Bernard J.F. Lonergan, Insight: A Study of Human Understanding (1958), p. 412. See also Bernard Lonergan, Method in Theology (1972), pp. 231-32; Understanding and Being: The Halifax Lectures on INSIGHT (The Collected Works of Bernard Lonergan. Vol. 5) (1990), pp. 109-130.

It should be noted that, on much of this diagnosis, Lonergan's judgment anticipated by thirty years that of Richard Rorty in Philosophy and the Mirror of Nature, (1979); "Solidarity or Objectivity?"' in Objectivity, Relativism and Truth: Philosophical Papers (1991), pp. 21-34. Of course, Rorty's and Lonergan's agreement extends only modestly past the diagnosis.

See also J. L. Mackie, Ethics: Inventing Right and Wrong (1977), pp. 38-42.

107. See Thomas Nagel, The View From Nowhere (1986); "The Limits of Objectivity" in The Tanner Lectures on Human Values (S. McNurrin, ed. 1980), Vol. 1, pp. 75-140.

108. Understanding and Being, pp. 175-76; Insight, pp. 377, 634.

109. Philosophy and the Mirror of Nature, p. 340.

110. Method, p. 19. 
the habit of the ocular metaphor, and attends to a realm of being that cannot be known by seeing." "The rock is the subject in his conscious, unobjectified attentiveness, intelligence, reasonableness, responsibility."112 To understand this "rock" of Lonergan's, we proceed in steps, but with this forewarning. Lonergan's work is as intensely focussed upon right reason and proper method as that of any gnostic. When, therefore, he emerges from his forest of philosophical correctness to of fer a happy ending for human equality, it comes almost as a surprise. It all fits, but it is not easy to explain. Now, the six steps:

First. "The rock ... is the subject." The move to the subject has begun: the rock is not what is external to me-the already-out-there that seemed waiting to be seen; it is rather an aspect of myself. It is discoverable not by the senses, but simply by being attentive to my own internality. ${ }^{113}$ While this notion will require some honing, its simplicity and scope demand notice. The subject-the self (myself) that has been the traditional threat to objectivity-is now the rock on which reliable knowledge may take its stand. If the blunders are to cease, one must notice, perhaps for the first time, the "neglected subject.",114

Second. It is not the subject simply-the totality of the personthat is rock, but the subject in his conscious "[1] attentiveness, [2] intelligence, [3] reasonableness, [4] responsibility." $\dot{W e}$ begin with the first three. Stop staring at what is outside, urges Lonergan. Attend to your own cognitive constitution. In it you will discover that these three invariant operations together bear your consciousness. None of them is at all exotic. They occur every time you know anything at all. "Attentiveness"level. Here data are given; the subject senses, perceives, imagines, feels, speaks, moves. "Intelligence"-the second-is distinct from this as the level at which the subject seeks the intelligibility in the data given by attentiveness. By insight into the data, the subject comes to understand, to produce ideas, concepts and formulations, and to work out the implications of those formulations. Third, there is "reasonableness" - the level of judgment. Here the subject affirms or denies what he has received in attentiveness and has understood

111. Ibid., pp. 7-9.

112. Ibid., pp. 19-20.

113. See Bernard Lonergan, "Cognitional Structure" in Collection (The Collected Works of Bernard Lonergan, Vol. 4) (F. Crowe, ed. 1988), pp. 205, 208-11.

114. "The Subject" in Bernard Lonergan, A Second Collection (W. Ryan, ed. 1974), p. 69. 
in intelligence. Here the subject reflects on the formulations produced by intelligence, marshals the evidence given in the data, and ultimately passes judgment: Adverting to the data, the subject says "yes" or "no" (or "probably" or "probably not") to the understanding of the data proposed by intelligence."1s

There remains a fourth and final internal operation to be discovered. Like those that preceded it, it is cognitive in nature; but this fourth operation involves more than knowing. This is the level of "responsibility"- of not merely knowing but deciding:

So far, our reflections on the subject have been concerned with him as a knower, as one that experiences, understands, and judges. We have now to think of him as a doer, as one that deliberates, evaluates, chooses, acts. Such doing, at first sight, affects, modifies, changes the world of objects. But even more it affects the subject himself. For human doing is free and responsible. ${ }^{116}$

On this level, Lonergan tells us, we are no longer just conscious; we become self-conscious. We affirm the real not just as what is, but as what is good and valuable; and we are faced with the decision of whether or not to choose the good and valuable. This is the level of freedom; it is here we decide what we are to do and to become. ${ }^{117}$

These four operations, then, are the invariant structures of consciousness and self-consciousness. Their existence can never be "proved" by catching a good look at them, but only by the subject's redirecting this whole series of operations to the internal process of knowing itself - that is, by attending to, understanding, and judging the very way we know. And here looms paradox or even contradiction. Any meaningful attempt to disprove the structure would itself prove that it exists and operates, for the would-be critic must himself attend to the evidence of its non-existence, understand and formulate this evidence, pass judgment upon it, and choose to make the denial. ${ }^{118}$

115. On these three operations, see Method, p. 9; Insight, pp. 271-78. On probabilistic judgments, see infra text at note 136. .

116. "The Subject,"' p. 79.

117. Method, p. 121. "So it is that the empirically, intelligently, rationally conscious subject of self-affirmation becomes a morally self-conscious subject. Man is not only a knower but also a doer; the same intelligent and rational consciousness grounds the doing as well as the knowing." Insight, p. 599.

In Insight Lonergan characterized this eros as one of the mind, while in Method it emerges more clearly as one that involves understanding but passes beyond to responsibility. See "An Exploration of Lonergan's New Notion of Value," p. 54. For Lonergan's own characterization of the difference in the treatment he gives this level in Insight and Method respectively, see "Insight Revisited" in A Second Collection, pp. 263, 272.

118. Method, p. 19; Insight, pp. 276-77. 
"[A]nyone that cares to deny [the operations'] existence is merely disqualifying himself as a non-responsible, non-reasonable, nonintelligent somnambulist." 119 These operations are rock.

Third. If all you discover in yourself, however, are these four operations, you have missed what is even more basic-the very condition of the possibility of their efficacy. These operations do not function at random. Before we ever attend to them, in every cognitive act they are already assembled and dynamically related to each other; already they have a structure and direction.

The operations ... stand within a process that is formally dynamic, that calls forth and assembles its own components. . . . It is a unity and relatedness that exists and functions before we manage to advert to it explicitly, understand it, objectify it. ${ }^{120}$

By attending to this already accomplished unity, the subject will discover that "[t]he many levels of consciousness are just successive stages in the unfolding of a single thrust, the eros of the human spirit." ${ }_{121}$ The ineradicable desire expresses itself in the curiosity, in the relentless questions that frame our meanings and set limits to our muddle-in questions for intelligence (What is it?), questions for understanding (Is it so?), questions for decision (Ought I to do it?). It is "a self-assertive spontaneity that demands sufficient reason for all else but offers no justification for its demanding." ${ }_{122}$ It is rock.

Fourth. Satisfaction of this desire is the fundamental criterion of human judgment and decision. But here we encounter a distinct if related set of terms. For this elemental cognitive satisfaction is achieved only by free adherence to what Lonergan calls the "transcendental precepts." These seek to rule us whether we affirm them or not. "[B]efore they are ever formulated in concepts and expressed in words, those precepts have a prior existence and reality in the spontaneous structured dynamism of human consciousness." 123 These precepts are four, each pre-figuring and governing one of the respective cognitive operations: "Be attentive, $\mathrm{Be}$ intelligent, $\mathrm{Be}$ reasonable, Be responsible." ${ }_{124}$ With these precepts the dynamic desire

119. Method, p. 17.

120. Ibid., p. 16. "[T] operations is part of the experience of the operations; and inquiry and discovery are needed, not to effect the synthesis of a manifold that, as given, is unrelated, but to analyze a functional and functioning unity." Ibid., p. 17.

121. Ibid., p. 13.

122. Insight, p. 332.

123. Method, p. 20.

124. Ibid., p. 20. 
of the human spirit "teaches". the subject that the point is not just autonomic sensing, understanding, judging and deciding. If the dynamic desire to know is to be satisfied, the subject must (1) sense attentively, (2) understand intelligently, (3) judge reasonably, and (4) decide responsibly. From within himself, but without his choosing it, the subject is called in freedom to be attentive, intelligent, reasonable, responsible.

Fifth. Normativity thus emerges from within the subject.

[It resides] at root in the native spontaneities and inevitabilities of our consciousness which assembles its own constituent parts and unites them in a rounded whole in a manner we cannot set aside without, as it were, amputating our own [4] moral personality, [3] our own reasonableness, [2] our own intelligence, [1] our own sensitivity. ${ }^{125}$

This normativity extends to all four operations, not merely the strictly "ethical" imperative of responsibility. It is also the nature of responsibility to presuppose and reaffirm the knowledge that emerges from the process of being attentive, ointelligent and reasonable. ${ }^{126}$ "We experience and understand and judge to become moral." ${ }_{127}$ If the subject is to be moral, i.e., responsible, then he must first have been attentive, intelligent, reasonable. ${ }^{128}$ Morality requires nothing less than fidelity to all four transcendental precepts.

Sixth. We begin to see the application to equality. By adhering to the transcendental precepts, by "genuine attention, genuine intelligence, genuine reasonableness, genuine responsibility," 129 objectivity-as Lonergan understands it-is achieved. That is, "[g]enuine objectivity is the fruit of authentic subjectivity." 130 By his fidelity to the transcendental precepts the subject literally creates the objectivity that is constituted in his own knowledge and decisions. This will prove to be the most controversial claim of Lonergan's ethics. But

125. Ibid., p. 18.

126. Lonergan describes this as "sublation." See ibid., p. 241. See "Cognitional Structure," p. 220; “The Subject," p. 80.

127. Bernard Lonergan, "Mission and the Spirit" in A Third Collection: Papers by Bernard J.F. Lonergan, S.J. (F. Crowe, ed. 1985), pp. 23, 29. See Insight, p. 604.

128. "[O]bjective knowing is not yet authentic human living; but without objective knowing there is no authentic living; for one knows objectively just insofar as one is neither unperceptive, nor stupid, nor silly; and one does not live authentically inasmuch as one is either unperceptive or stupid or silly." "Cognitional Structure," p. 220.

129. Method, p. 265.

130. Ibid., p. 292. 
it is this very reentry into the self that promises to reconcile human equality and objectivity; it is, therefore, important to clarify why fidelity to this "subjective" standard does not end for Lonergan in a pure subjectivism.

Though it takes some getting used to, the reason is simple: the dynamic desire for understanding could be finally and fully satisfied by nothing less than what is real. It is the desire not for fantasy, fiction, or even for unknowably true perceptions, but for what isfor what is real, for the "external" world. It is, in a word, a transcendent desire. That dynamic desire has reality (the "external" world) as its goal; hence it moves the subject beyond his interiorityfrom slumber to sensing, to understanding, to judging, to deciding. ${ }^{131}$ When it has been temporarily satisfied (the desire always presses for more), this is exactly because a judgment or decision has been reached regarding the "external" world and celebrating its reality. "[T]here is," therefore, "no problem of a bridge [from the subject to the external world]. If you can reach the judgment [or decision], you

131. "The objectivity of human knowing, then, rests upon an unrestricted intention and an unconditioned result. Because the intention is unrestricted, it is not restricted to the immanent content of knowing ...., we can ask whether there is anything beyond that, and the mere fact that the question can be asked reveals that the intention which the question manifests is not limited by any principle of immanence. But answers are to questions, so that if questions are transcendent, so also must be the meaning of [any relevant] answers." ("Cognitional Structure," p. 213 (first emphasis added)). Our paraphrase "[any relevant]" replaces Lonergan's word "corresponding," which in present context might suggest the match between thought and external thing that is exactly what Lonergan does not mean.

Lonergan elaborates the point in a manner irritatingly complex but ultimately clear: "If I am asked whether mice and men really exist, I am not answering the question when I talk about images of mice and men, concepts of mice and men, or the words, mice and men; I answer the question only if I affirm or deny the real existence of mice and men. Further, true answers express an unconditioned. Mice and men are contingent, and so their existence has its conditions. My knowing mice and men is contingent, and so my knowing of their existence has its conditions. But the conditions of the conditioned may be fulfilled, and then the conditioned is virtually an unconditioned; it has the properties of an unconditioned, not absolutely, but de facto. Because human knowing reaches such an unconditioned, it transcends itself. . . . The possibility of human knowing, then, is an unrestricted intention that intends the transcendent, and a process of self-transcendence that reaches it. The unrestricted intention directs the process to being; the attainment of the unconditioned reveals that at some point being has been reached. . . . Without the dynamism one may speak of concepts of being, of affirmations of being, even the idea of being; but unfailingly one overlooks the overarching intention of being which is neither concepts nor affirmation nor idea." (Ibid., pp. 213-14. See Insight, p. 284). "The ultimate basis of our knowing is not necessity but contingent fact, and the fact is established, not prior to our engagement in knowing, but simultaneously with it." Ibid., p. 332. 
are there." ${ }^{132}$ The fact of authentic judgment and decision completes the journey to reality; there is no bridge to be crossed. Immanentism is avoided and objectivity is achieved, not by decamping (with Nagel) from our subjective locus, but instead by authenticity in knowing and deciding. That is real objectivity-and the only one we can know.

Lonergan's dual message is that authenticity gets you to reality and that there is no human shortcut. If you follow the four transcendental precepts, you will get there; but one must take the many steps the precepts demand. Note, however, that there is no terrestrial end to those steps, because there is no terrestrial end to the dynamic desire to know. That desire will be satisfied (and certainty about the "external" world will be achieved) only when all relevant questions about it are answered. ${ }^{133}$ But there is not time for the subject to hear, let alone to answer, all relevant questions about everything, and the subject cannot "postpone his living, until he has learned, until he has become willing, until his sensitivity has been adapted" 134 - until he has answered all of the questions. We are, "[i]n [Gerard Manley] Hopkins' phrase, . . . 'time's eunuch." "135 Our knowledge of the "external" world must remain probabilistic; what we actually know about it are, in Lonergan's phrase, "emergent probabilities."136

The dynamic desire to know may demand-indeed, frequently demands-that one judgment be supplanted by another; a judgment that was authentic when made must yield to one issuing from fresh attentiveness, intelligence, reasonableness, responsibility: "Authenticity does not prevent mistakes in the short run, but it does tend to overcome mistakes in the long run, when our relevant questions find their quarry," even though "this 'short run' may be the entire life of an individual or a culture." 137 This is no justification for junking the transcendental precepts and becoming a Descartes. The unavailability of absolute certainty about the details of the "external" world does not call everything into doubt. The transcendental precepts press upon the subject (they are an aspect of the subject), and they at least are certain. Although the answers to questions about the "external" world are always subject to revision, "there is no revision

132. Understanding and Being, p. 172.

133. Insight, p. 284.

134. Ibid., p. 689.

135. Tad Dunne, Lonergan and Spirituality (1985), p. 62.

136. See Insight, pp. 115-28, 259-62, 272, 299-304, 510, 549-52.

137. Lonergan and Spirituality, p. 62. 
of the revisers themselves."'38 The transcendental precepts govern any revision, and what they counsel is not skepticism, but a cautious openness or-in now familiar words-attentiveness, intelligence, reasonableness, responsibility. The transcendental precepts are rock.

In still other words, what our own being obliges is authenticity in the present; the subject must resist the urge to metamorphose probabilities into pseudo-certainties, repose in those achievements, and give up the search. You have finally concluded that this war is unjust; keep thinking. The necessity of continued search rests upon the constancy of the dynamic and inescapable desire to know. No one is in a privileged position (with Nagel), no one exempt or sent on vacation. Everyone must be-equally and constantly-a seeker. "Emergent probability [that is, the unavailability of a permanent factual knowledge that will put an end to the search,] is the great equalizer of humankind." ${ }^{139}$ No discovery liberates the subject from making the search, from continuing in the service of the dynamic desire to know, from obeisance to the transcendental precepts.

Authenticity is not automatic or effortless. "Concretely it remains difficult to tell whether or not we are being authentic." ${ }^{140}$ Selfdelusion is easy enough. The transcendental precepts can be evaded. One can be inattentive, unintelligent, unreasonable, irresponsible. Even among those who try to observe them, the precepts will not operate "with anything like mechanical efficiency." 141 The subject who would be authentic must engage in a self-correcting process. ${ }^{142}$ Accepting ourselves as we are, we must make the most of it-not by climbing outside of ourselves, but by attentiveness, intelligence,

138. Insight, p. 177.

139. Lonergan and Spirituality, p. 66.

140. Ibid., p. 61 .

141. "An Exploration of Lonergan's New Notion of Value," p. 62.

142. First there must be "conversion." "Moral conversion changes the criterion of one's decisions and choices from satisfactions to values.... Such conversion ... falls far short of moral perfection." Method, 240. And with that the work has just begun. "One has yet to uncover and root out ... bias. One has to keep developing one's knowledge. ... One has to keep scrutinizing one's intentional responses.... One has to listen to criticism and to protest. One has to remain ready to learn from others. For moral knowledge is the proper possession only of morally good men and, until one has merited that title, one has still to advance and to learn." Ibid. (footnote omitted; emphasis added). (See ibid., pp. 2, 268). "It is ... only by reaching the sustained self-transcendence of the virtuous man that one becomes a good judge, not on this or that human act, but on the whole range of human goodness." Method, p. 35.

See "Lonergan's New Notion of Value," pp. 61-62. 
reasonableness and, then, responsibility. ${ }^{143}$ To accept a universe of emergent probabilities that we can know only through fidelity to the transcendental precepts "means to let the spirit of inquiry roam across a battlefield, returning scarred and exhausted perhaps, but never mortally wounded by the combat." 144 It means to stay in the struggle.

Lonergan's central insight, then, is that the question of whether the subject has reached objectivity can be answered in only one way, $v i z .$, by assessing whether he has been authentic. The question cannot be answered in any other way, because the only way to know whether one has reached what transcends the subject is to ascertain whether one has been faithful to the transcendental precepts.

It is this fundamentality of the transcendental precepts and of personal authenticity that makes equality a possibility. The question of whether people have the equal capacity to achieve objectivity in their moral judgments has been transmuted into the question of whether they have the same capacity to be authentic, and the answer seems to be yes. Moving ethics in from the external to the internal world dissolves the problem of "equal access;" because objectivity's norms are internal, everyone can know and satisfy them. The principle is not correspondence to the external, but fidelity to the internally given transcendental precepts.

That principle gives rise to instances of the good, but those instances are good choices and actions. However, do not ask me to determine them, for their determination in each case is the work of the free and responsible subject producing the first and only edition of himself. ${ }^{145}$

This must not be mistaken for moral laxism. Whether the subject is authentic is radically contingent upon whether he has made the relentless struggle ${ }^{146}$ to meet the demands of a command of which he cannot plead ignorance. ${ }^{147}$

Will is good .... in the measure that antecedently and without persuasion it matches the pure desire both in its detachment from the sensitive subject and in its incessant dedication to complete

143. Ibid., pp. 62-63 n.55. See Insight, pp. 691-92.

144. Lonergan and Spirituality, pp. 69-70.

145. "The Subject," p. 83. "By his own acts the human subject makes himself what he is to be, and he does so freely and responsibly; indeed, he does so precisely because his acts are the free and responsible expressions of himself." Ibid., p. 79. See Method, p. 38; Understanding and Being, p. 234. See Lonergan, p. 131.

146. See Insight, p. 278.

147. See ibid., p. 689. 
intelligibility. A will less good than that is less than genuine; it is ready for the obnubilation that takes flight from self-knowledge; it is inclined to the rationalization that makes out wrong to be right. . . . In brief, as man's intelligence has to be developed, so also must his will. But progress in willingness is effected by persuasion, persuasion rests upon intelligent grasp and reasonable judgment, and so the failure of the intellect to develop entails the failure of the will. ${ }^{148}$

This does not threaten, but instead assures equality, because it never requires of the subject that he do more than heed the inner commands to be attentive, intelligent, reasonable, responsible. But the work of meeting these commands must not be underestimated; it is the constant business of a lifetime. ${ }^{149}$

So we conclude with Lonergan: Yes, there is a genuine order of obligation; yes, we must heed its commands; no, we never get outside to check whether we have got its terms right. The most we can do is to make the search in the enthusiasm of the dynamic desire for the good that promotes us from one step to the next. Whatever perfection is possible lies in making this search; thus, though we cannot be certain, it is plausible that all persons are uniformly prepared to do what is necessary. Lonergan blesses what is a proxy marriage of the real good to the authentic person. ${ }^{150}$

To identify these transcendental precepts as the natural law may prove controversial, but it should not. There is some justification for it even in Aquinas, ${ }^{151}$ and Lonergan himself, though he did not use the expression (he would not have wanted his notion of the natural law confused with the hopeless mess of other meanings), seems to have approved it, ${ }^{152}$ as have his intellectual heirs. ${ }^{153}$ Terminology aside, Lonergan's influence upon the course of natural law theorizing seems likely to grow. There appears no creditable way

148. Insight, pp. 691-92.

149. See ibid., p. 689.

150. For a more elaborate assessment of whether Lonergan can be harmonized with equality, see J. Coons and P. Brennan, "Created Equal: Lonergan Explains Jefferson," in Lonergan Workshop (F. Lawrence, ed. 1995).

151. See Aquinas, Summa theologiae, Ia-Ilae, q. 94, aa. 1-2.

152. Bernard J.F. Lonergan, "The Transition from A Classicist World-View to Historical Mindedness" in A Second Collection, pp. 1, 2; Insight, p. 618.

153. David Granfield, The Inner Experience of Law: A Jurisprudence of Subjectivity (1988), pp. 177-216 et passim. Michael Novak, "Bernard Lonergan: A New Approach to Natural Law" in 41 Proceedings of the American Catholic Philosophical Association (1967), p. 246: "Natural law is not constituted by an 'objective code;' it is constituted by a set of dynamically related operations on the part of each individual person." Ibid., p. 249 (citation omitted). 
for its champions to ignore his invitation to bring the possibility of moral self-perfection in from the cold of external correctness. They may in the end reject it, but first they must deal with it. The experience may prove rejuvenating, and human equality comes as a bonus.

Lonergan's reconciliation with the more traditional interpretations of natural morality could be facilitated by taking one easy step back (or perhaps forward) in the direction of Aristotle. Recall that both the Common Sense and Classic schools have continued to express individual self-perfection in terms of Aristotle's familiar dyad of the potential and the actual. The natural finality of any being lies in its capacity for a certain perfected state being changed into the realization of that state. In the case of a flower this fulfillment consists in completion of the full cycle of its possibilities-from seed to blossom to seed. That is the flower's perfection, and animal finality is a close if more complex parallel. The real puzzle appears only when we inquire about the perfection of man; what is the natural finality of a rational, voluntary animal?

Aristotle and his intellectual descendants-including Aquinas and Suarez-never broke free from the limiting notion that the natural moral fulfillment of human beings requires a form of realization that is experienced in the external order-one that has cognitive, material and social achievements as necessary ingredients. No one is completed unless he or she is in some degree a "success"; as they would prefer to put it, natural fulfillment entails some measure of earthly happiness. Earlier we saw this view still flourishing in modern philosophers such as Martha Nussbaum, as well as the traditional naturalists.

We would not denigrate temporal happiness (all of us seek it), but we grieve that natural lawyers remain content with a notion of man's natural finality that is so vulnerable and utterly contingent. There is, after all, another plausible view of fulfillment. There is a kind of finality that is unthreatened by bad luck and-more to the pointone of greater nobility than mere external success. Nor is there anything in the least unnatural about the human capacity that makes possible the sort of perfection we have in mind. The traditionalists agree that, by their very constitution, humans are invited to seek the objective good. What, then, would be the potential that is left unactualized in the person who in fact seeks? The shortfall in his fulfillment could amount at the very most to the ephemera of the external-wealth, leisure, beauty, knowledge, friendships, reputationall of it blowing in the wind. How could these contingent blessings compare in nobility to the unconditional good that is open to the 
seeker, whatever his circumstances, and whose moral estate remains incorruptible to all save his own will? If it be true that the free pilgrims of the good achieve moral fulfillment, obtension is man's natural finality. ${ }^{154}$ Period.

\section{A Fragment on Habit, Virtue and Vice.}

Natural lawyers-particularly of the Common Sense and Classic stripe-traditionally accord a cardinal role to virtue and vice in the moral life. Aquinas, for example, considered virtue to be, like law, one of the necessary means by which a person is led to his perfection. ${ }^{155}$ We concede that good habits may enhance a person's chances of discovering and realizing specific good behaviors, and "vice" versa. We conclude, however, that neither the relative advantage of the well-habituated nor the relative disadvantage of the ill-habituated represents a threat to equality. Virtue may be an aid to finding specific correct behaviors, but even the most vicious person is fully capable of obtending. Whether with good habits or bad, every one of us retains in uniform degree the capacity to try for the good.

One could, of course, take virtue to be a synonym for obtension. That is, to natural lawyers virtue could be the name for whatever activity it is that produces self-perfection. At first this seems unlikely. In practice, the naturalists have assigned virtue only a bit part in the morality play. In the classic tradition, for example, virtue helps (and vice hinders) correct acts, but it is the acts themselves that are necessary and (with proper intention) sufficient to rectitude.

But this oversimplifies the history of natural theories. The moral significance of simply keeping rules is notoriously obscure, and only a crude behaviorist would accept it as the whole story about the moral man. Recently natural moralists have begun to emphasize virtue more than rule-abidingness as the measure of a man's moral perfection. The question for them has become less what an actor did than what is the meaning of the particular act in the context of the person's entire character. This new focus upon virtue has made it to popular media such as Newsweek: "What ... a variety of ...

154. Cf. Lonergan, "Natural Right and Historical Mindedness," in $A$ Third Collection, p. 172: "Now Aristotle defined a nature as an immanent principle of movement and of rest. In man such a principle is the human spirit as raising and answering questions. As raising questions, it is an immanent principle of movement. As answering questions and doing so satisfactorily, it is an immanent principle of rest."

155. See Summa theologiae, Ia-IIae, Prologue to "Treatise on Habits" and Prologue to "Treatise on Law." See also ibid., q.58, a.2. 
influential thinkers . . . propose is the renewal of the idea of virtueor character-as the basis for both personal and social ethics." 156 This turn from rules to internal states of the person has taken shapes too numerous for inventory here. ${ }^{157}$ Overall it appears congenial to equality. Indeed, it has been a temptation to equate obtension with virtue, and it is important to see why that conflation would be false.

Whatever else it may be, obtension is an activity; specifically, it is the activity of questing after the good. It is doing something; it is doing one's best. It is this dynamic element that the term "virtue" fails to capture. From the time of Aristotle, virtue and vice have been understood to be passive states of the person-the one favorable to good behaviors, the other to evil. They are internal environments. A person, then, might have every virtue, and these might add up to that medley we call good character; yet he might or might not, at any particular time, be striving for the good. Aristotle insisted upon this very point; virtue is but a passive state, while human perfection is an activity. ${ }^{158}$ To be sure, by a subtle shift in usage the moral theorist could limit the state of virtue to those who are busy seeking the apparent good. But an important distinction would be lost. Hence, some separate term (we prefer obtension) is necessary to distinguish virtue from the active questing that augments moral selfperfection by exercise of a capacity whose plausible uniformity is the capstone of human equality.

In any case, there is a strong stylistic reason not to equate obtension with virtue. Ordinarily, virtue is said to incline the person toward specific real goods-to correct moral answers. Newsweek is typical in maintaining that "virtue . . . is a quality of character by which individuals habitually recognize and do the right thing." 159 It would

156. Kenneth L. Woodward, "What Is Virtue?" in Newsweek (June 13, 1994), pp. $38,39$.

157. Preeminent among these are After Virtue, in which Macintyre argues for something like Aristotle's account of the virtues but shorn of Aristotle's "metaphysical biology" (148), and Stanley Hauerwas's Character and the Christian Life: $A$ Study in Theological Ethics (1985), in which Hauerwas makes virtue and character, in the tradition of Aristotle and Aquinas, a concern for Protestant ethics. Also noteworthy is Jean Porter, The Recovery of Virtue (1990). But cf. Russell Hittinger, "Natural Law and Virtue: Theories at Cross Purposes" in Natural Law Theory, pp. 42-69.

158. This is an instance of the general Aristotelian preference for act over potency. See also The Fragility of Goodness, pp. 322-27, espec. 324.

159. "What is Virtue" (emphasis original). Aquinas, for example, limits virtue to those states of character that are in accord with right reason and thus incline their possessor to specific correct choices. See James Keenan, Goodness and Rightness in Thomas Aquinas's Summa Theologiae (1992), pp. 92-116: "[T]he moral virtues concern attainment, not striving. ... In the ambit of Thomas's discussion on the moral virtues, his goodness always means our rightness." Ibid:, p. 105. 


\section{THE AMERICAN JOURNAL OF JURISPRUDENCE (1995)}

be odd to ascribe virtue to the diligent and conscientious bungler who is the picaresque ensign of human equality.

In respect to the proper characterization of the moral life, among the naturalists it is Lonergan who comes closest to our own position. Moral life is a series of demands for personal responsibility; moral self-perfection is achieved by the effort to meet each demand as it arises; and the person who is passive in the face of those demands amputates his own moral personality. The question about whether a person is morally self-perfecting is not whether he is habitually disposed to the real good, but whether he is responsible-whether he is striving as much as is in him to find and to do the good. On that proposition we conclude that natural lawyers have gone both ways. 